University of Nebraska - Lincoln

DigitalCommons@University of Nebraska - Lincoln

2005

Puffins, Pigs, Cod, and Barley: Palaeoeconomy at Undir

Junkarinsfløtti, Sandoy, Faroe Islands

Mike J. Church

Símun V. Arge

Seth Brewington

Thomas H. McGovern

Jim M. Woollett

See next page for additional authors

Follow this and additional works at: https://digitalcommons.unl.edu/global

Part of the Archaeological Anthropology Commons, Geography Commons, and the International and Area Studies Commons

This Article is brought to you for free and open access by the School of Global Integrative Studies at DigitalCommons@University of Nebraska - Lincoln. It has been accepted for inclusion in Global Studies Papers \& Publications by an authorized administrator of DigitalCommons@University of Nebraska - Lincoln. 


\section{Authors}

Mike J. Church, Símun V. Arge, Seth Brewington, Thomas H. McGovern, Jim M. Woollett, Sophia Perdikaris, Ian T. Lawson, Gordon T. Cook, Colin Amundsen, Ramona Harrison, Yekaterina Krivogorskaya, and Elaine Dunbar 
Published in Environmental Archaeology 10:2 (2005), pp. 179-197; doi: 10.1179/env.2005.10.2.179 Copyright (C) 2005 Taylor \& Francis. Used by permission.

Submitted December 2004; revised and accepted March 2005; published online July 18, 2013.

\title{
Puffins, Pigs, Cod, and Barley: Palaeoeconomy at Undir Junkarinsfløtti, Sandoy, Faroe Islands
}

Mike J. Church, ${ }^{1}$ Símun V. Arge, ${ }^{2}$ Seth Brewington, ${ }^{3}$

Thomas H. McGovern, ${ }^{4}$ Jim M. Woollett, ${ }^{5}$ Sophia Perdikaris, ${ }^{6}$

Ian T. Lawson, ${ }^{7}$ Gordon T. Cook, ${ }^{8}$ Colin Amundsen, ${ }^{3}$ Ramona Harrison, ${ }^{3}$

Yekaterina Krivogorskaya, ${ }^{3}$ and Elaine Dunbar ${ }^{8}$

1. Department of Archaeology, University of Durham, South Road, Durham, DH1 3LE, United Kingdom

2. Føroya Forminnissavn, Hoyvik, Tórshavn, Føroyar

3. CUNY Northern Science and Education Center, Department of Anthropology and Archaeology, Brooklyn College, Brooklyn, New York, USA

4. Anthropology Department, Hunter College CUNY, New York City, New York, USA

5. Département d'histoire, Université Laval, Québec City, Québec, Canada

6. Brooklyn College Zooarchaeology Laboratory, Department of Anthropology and Archaeology, Brooklyn College, Brooklyn, New York, USA

7. School of Geography, University of Leeds, Leeds, United Kingdom

8. Scottish Universities Environmental Research Centre, Radiocarbon Dating Laboratory, East Kilbride, United Kingdom.

Corresponding author - Mike J. Church, Department of Archaeology, University of Durham, South Road, Durham, DH1 3LE, United Kingdom, email m.j.church@durham.ac.uk

\begin{abstract}
This paper reports on the zooarchaeological and archaeobotanical remains from the initial season of excavations at the Norse period site at Undir Junkarinsfløtti in the Faroe islands. These remains represent the first zooarchaeological analysis undertaken for the Faroes and only the third archaeobotanical assemblage published from the islands. The excavated deposits are described and the key
\end{abstract}


findings from the palaeoenvironmental remains highlighted within the context of the wider North Atlantic environmental archaeology of the Norse period.

Keywords: Faroes, North Atlantic, Landnám, zooarchaeology, archaeobotany

\section{Introduction}

The Faroes consist of a cluster of 18 small islands in the North Atlantic c. $300 \mathrm{~km}$ northwest of Shetland and c. $780 \mathrm{~km}$ southeast of Reykjavik, Iceland (Fig. 1). The climate is wet, windy, and comparatively mild for the latitude $\left(62^{\circ} \mathrm{N}, 7^{\circ} \mathrm{W}\right)$, a function of the islands' position within the Gulf Stream. The Faroes were not settled until the late first millennium AD, perhaps by a small number of Irish ecclesiastical hermits in the 7th to early 9th century, according to contemporary literature (De mensura orbis terrae written in AD 825 by the Irish monk Dicuil) and equivocal palaeoenvironmental evidence (cf. Jóhansen 1985; Hannon et al. 2001). The first well-documented period of substantial settlement occurred during the ninth century AD with the arrival of Norse settlers (Arge 1991; 1993; Debes 1993). This settlement, or landnám ("land taking" in Old Norse), within pristine or near-pristine landscapes is a key feature of the archaeology of the North Atlantic islands (McGovern 2004). Norse Landnám occurred in Iceland between AD 870-880 and approximately AD 1000 in Greenland, and each island group provides opportunities to examine human-environment impacts on these near-pristine landscapes. The Faroes Iceland-Greenland "transect," from the eastern to western North Atlantic, spans an environmental continuum that grows increasingly Arctic (colder and more continental) in character as both the marine and atmospheric polar fronts are crossed. Viking and Norse period archaeology in the Faroes is therefore very important, as it represents the first temperate stepping stone in this transect and also the first pristine landscape facing the Norse settlers. This novel landscape would have posed unique questions for the survival and failure of the Norse, and their adaptation to this alien environment would inform the success of subsequent generations of Norse settlers.

Environmental archaeology has a key role in identifying the nature of this humanenvironment interaction. The timing and environmental impact of settlement has been investigated for over thirty years in Faroese research, through the analysis of various palaeoenvironmental records in lake sediments and peat, including palynology (Jóhansen 1971; 1975; 1982; 1985), plant macrofossils (Bennike et al. 1998), insects (Buckland 1990; Buckland and Dinnin 1998) and multiproxy investigations (Buckland et al. 1998; Hannon et al. 1998; 2001) within a chronological framework provided by radiocarbon dating and tephrochronology (Dugmore and Newton 1998; Hannon and Bradshaw 2000; Wastergård 2002). Conversely, few analyses have been published concerning ecofacts and environmental remains on archaeological sites, covering only plant macrofossils (Malmros 1990; 1994; Vickers et al. in press) and pollen and insect remains (Edwards et al. 1998). 


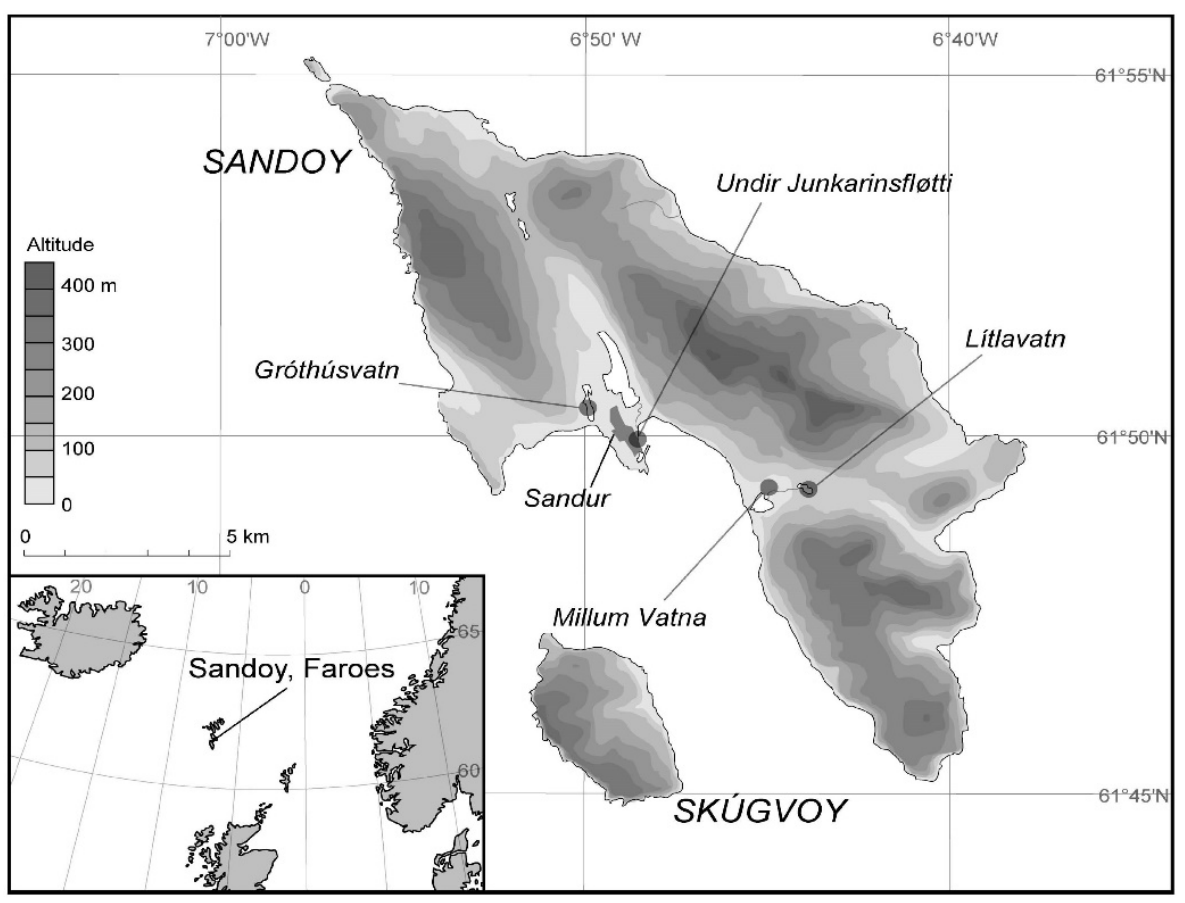

Figure 1. Location map of Undir Junkarinsfløtti.

A new international, multidisciplinary research project funded by the Leverhulme Trust investigating the impact of landnám on the pristine landscapes of the North Atlantic islands (Edwards et al. 2004; Dugmore et al. 2005) has identified the need to integrate the offsite palaeoenvironmental record of the Faroes with detailed insights into the economic practices of the Norse settlers, afforded through onsite environmental archaeology (Lawson et al. in press). The recent excavations at Undir Junkarinsfløtti on the island of Sandoy (Fig. 1) represented a key site for investigating early Faroese palaeoeconomy. The archaeology consisted of a series of Viking and Norse period middens exposed by coastal erosion in the sandy soil of the infield of the nearby village of Sandur. The middens were first identified in 2000 after slumping caused by a prolonged dry period, with an initial trialtrenching exercise by Føroya Forminnissavn (Faroes National Museum) recording a series of bone- and ash-rich middens over two meters high (Arge 2001). Two radiocarbon dates from the two lowest midden deposits produced determinations (AAR-6928 and AAR-6929, see Table 1) of the landnám period (9th-10th centuries cal. AD). The early dating of the site was reinforced by the discovery of a Viking period bronze brooch of 10 th century cal. AD date in the same layer. In 2003, the sondage first excavated in 2000 was enlarged to extract zooarchaeological and archaeobotanical remains and undertake geoarchaeological analysis. A further season of excavation of the area immediately behind the eroding edge in 2004 has revealed a Late Norse structure associated with the upper levels of the eroding midden deposits. This paper presents the environmental analyses from the 2003 season and places the findings in the wider context of Norse period palaeoeconomy in the North Atlantic islands. 


\begin{tabular}{|c|c|c|c|c|c|c|}
\hline Code & Context & Phase & Sample Type & ${ }^{13} \mathrm{C}$ & ${ }^{14} \mathrm{C}$ Age & $\begin{array}{c}\text { Calibrated range } \\
\text { (2 using Bronk-Ramsey 2003) }\end{array}$ \\
\hline SUERC-3422 & 3 & UJF3 & Barley grain & -24.6 & $925 \pm 40$ & $1020-1210 \mathrm{cal}$ AD \\
\hline SUERC-3417 & 16 & UJF2 & Barley grain & -25.9 & $900 \pm 35$ & $1030-1220 \mathrm{cal}$ AD \\
\hline SUERC-3418 & 16 & UJF2 & Barley grain & -26.4 & $925 \pm 40$ & $1020-1210 \mathrm{cal}$ AD \\
\hline AAR-6927 & 19 & UJF2 & Sheep bone & -19.8 & $950 \pm 35$ & 1010-1190 cal AD \\
\hline SUERC-3423 & 22 & UJF1 & Cow bone & -20.9 & $990 \pm 35$ & 980-1160 cal AD \\
\hline SUERC-3424 & 22 & UJF1 & Pig bone & -21.2 & $1035 \pm 35$ & $890-1160 \mathrm{cal}$ AD \\
\hline SUERC-3400 & 23 & UJF1 & Barley grain & -23.9 & $1000 \pm 40$ & 970-1160 cal AD \\
\hline SUERC-3401 & 23 & UJF1 & Barley grain & -26.8 & $980 \pm 40$ & 980-1170 cal AD \\
\hline SUERC-3402 & 23 & UJF1 & Barley grain & -26.3 & $940 \pm 45$ & $1010-1220 \mathrm{cal} \mathrm{AD}$ \\
\hline SUERC-3403 & 23 & UJF1 & Barley grain & -24.0 & $995 \pm 35$ & 980-1160 cal AD \\
\hline SUERC-3410 & 23 & UJF1 & Pig bone & -21.4 & $965 \pm 40$ & 990-1190 cal AD \\
\hline SUERC-3411 & 23 & UJF1 & Pig bone & -21.0 & $1075 \pm 40$ & $890-1030 \mathrm{cal} \mathrm{AD}$ \\
\hline SUERC-3415 & 23 & UJF1 & Pig bone & -21.4 & $935 \pm 40$ & $1020-1210 \mathrm{cal}$ AD \\
\hline SUERC-3416 & 23 & UJF1 & Pig bone & -21.6 & $1005 \pm 35$ & 970-1160 cal AD \\
\hline SUERC-3425 & 23 & UJF1 & Cow bone & -21.0 & $980 \pm 40$ & 980-1170 cal AD \\
\hline SUERC-3426 & 23 & UJF1 & Pig bone & -22.7 & $1095 \pm 40$ & 880-1030 cal AD \\
\hline AAR-6929 & 23 & UJF1 & Cow bone & -19.9 & $1115 \pm 35$ & $780-1020 \mathrm{cal} \mathrm{AD}$ \\
\hline AAR-6928 & 24 & UJF1 & Sheep bone & -20.4 & $1190 \pm 40$ & 710-980 cal AD \\
\hline
\end{tabular}

\section{Research Aims}

Three main research aims were identified at the outset of the 2003 excavations:

1) To date the sequence of midden deposits through the provision of multiple AMS radiocarbon dates;

2) To establish both the site formation processes of the midden deposits and, where possible, the taphonomy of the ecofacts;

3) To undertake detailed zooarchaeological, archaeobotanical and geoarchaeological sampling and analyses throughout the excavated sequence, with a view to reconstructing Norse palaeoeconomic practices.

These aims were investigated through the integrated use of the methods outlined in the following section.

\section{Methods}

\section{Excavation and sampling}

The 2003 excavations aimed to enlarge the small sondage first excavated in 2000. Excavation was started at the top of the eroding section, and the deposits were excavated in a series of three shored steps to ensure safe working conditions (Fig. 2). A composite section of most of the archaeological deposits is presented in Figure 3, running from the Medieval 
sterile sand overburden (Context 2) down to the lowest midden deposit (Contexts 23 and $24)$, overlying the presettlement soil interface with the glacially derived subsoil (Context 25).

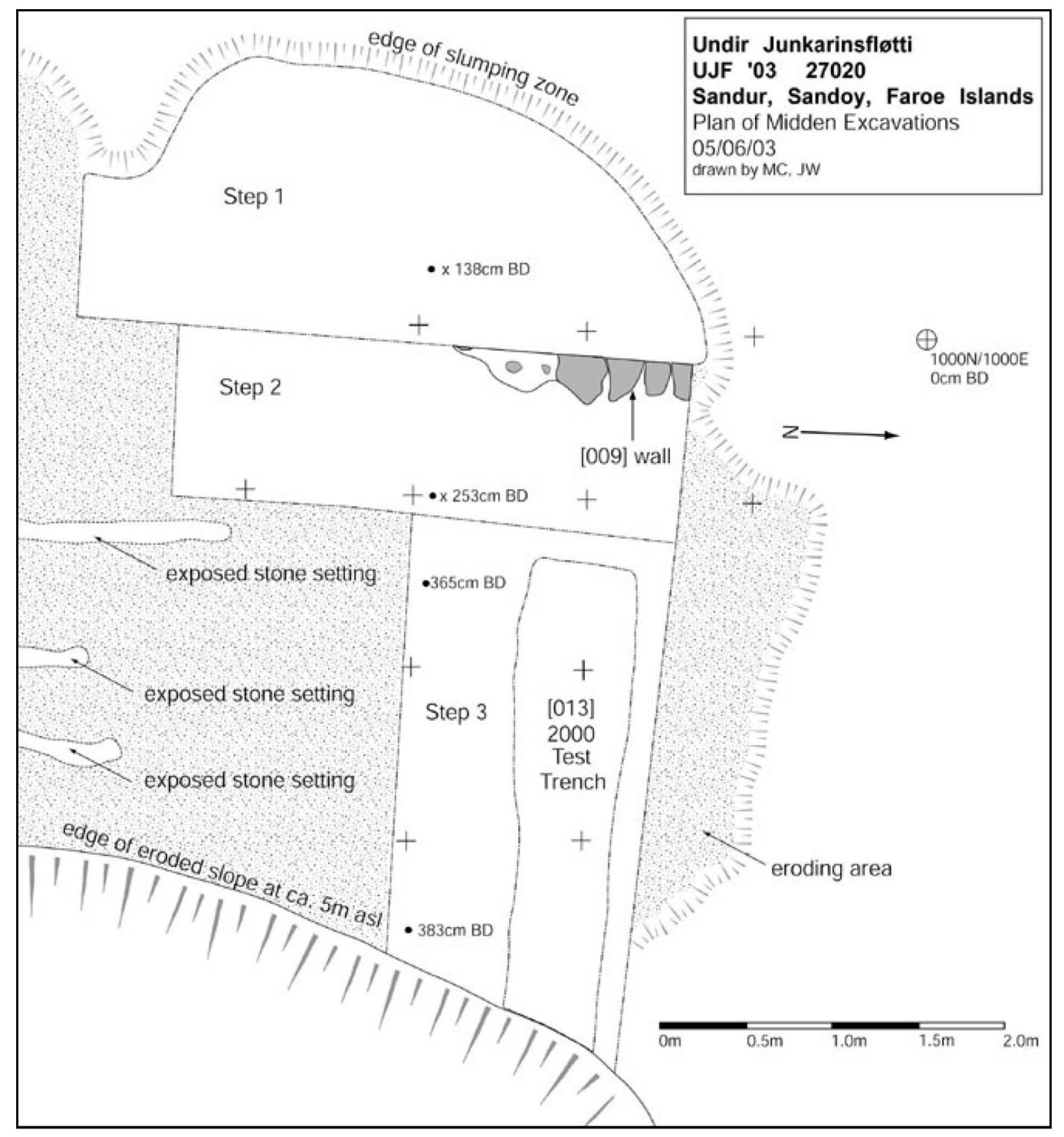

Figure 2. Site plan of Undir Junkarinsfløtti. 


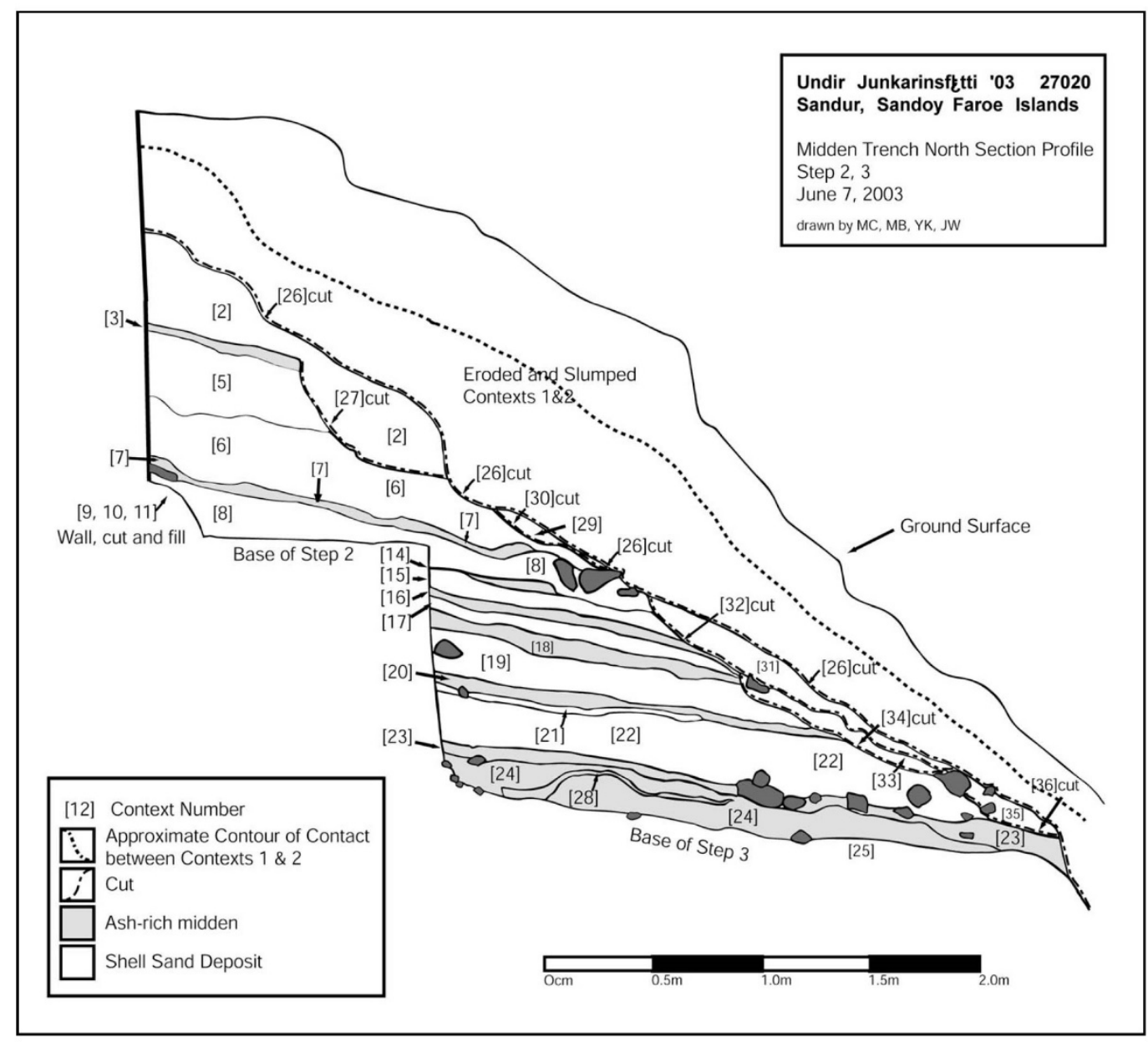

Figure 3. South-facing section of Steps 2 and 3 of Undir Junkarinsfløtti.

All of the archaeological deposits were dry-sieved at $4 \mathrm{~mm}$ for the extraction of zooarchaeological remains and artifacts, a sieving strategy consistent with other NABO (North Atlantic Biocultural Organization) excavations in Iceland and Greenland (McGovern 2004). The integrated use of soil micromorphology with bulk and routine soil samples was also undertaken to explore the research questions. A total sampling strategy (Jones 1991) was employed, involving the removal of bulk samples of between two and twelve liters from every excavated sediment context. Generally these samples represented less than $5 \%$ of the total volume of context excavated. Routine samples of c. 0.1 liters were taken from these bulk samples for sedimentary analysis. Kubiena tins were column sampled from layers throughout the exposed section for thin section preparation for soil micromorphological analysis. This analysis is still ongoing and will be reported elsewhere. 


\section{Laboratory and quantitative methods}

Analysis of the Undir Junkarinsfløtti zooarchaeological collection was carried out at the Brooklyn College and Hunter College Zooarchaeology Laboratories using comparative skeletal collections of both laboratories and of the American Museum of Natural History. All fragments were identified as far as taxonomically possible, but most mammal ribs, long bone shaft fragments, and vertebral fragments were assigned to "large terrestrial mammal" (cattle-horse sized), "medium terrestrial mammal" (sheep-goat-pig-large dog sized), and "small terrestrial mammal" (small dog-fox sized) categories. Only elements positively identifiable as Ovis aries L. were assigned to the "sheep" category, with all other sheep/goat elements being assigned to a general "caprine" category potentially including both sheep and goats. Murre (Uria aalge L.) and guillemot (Uria lomvia L.) are not distinguishable except on the beak and lower jaw, and are presented together as Uria sp., except where positive identification of guillemot could be made. Only some fish elements allow positive species-level identification, thus creating a large cod-family or "gadid" category as well as a substantial number of unidentified fish bones. Following NABO Zooarchaeology Working Group recommendations and the established standards of North Atlantic zooarchaeology, a simple fragment count (NISP) formed the basis for most quantitative presentation (cf. Amorosi et al. 1996).

The bulk samples were processed using a Siraf type wet sieve tank (Kenward et al. 1980), using 1.0 and $0.3 \mathrm{~mm}$ sieves for the flot and a $1.0 \mathrm{~mm}$ sieve net to catch the residue. The material was air dried, and both the flot and residue fully sorted under $\times 6-20$ magnification. The $0.3 \mathrm{~mm}$ flot was scanned for any different type or species of plant macrofossil not recovered in the $1.0 \mathrm{~mm}$ fractions, but as none were forthcoming no further sorting of the $0.3 \mathrm{~mm}$ flot was undertaken. Charcoal was sorted only from the $>4 \mathrm{~mm}$ fraction, as identification is very difficult below this size (Pearsall 2000, 130). Uncarbonized plant macrofossil preservation has been shown to exist on previous Faroese excavations (cf. Malmros 1994; Edwards et al. 1998; Vickers et al. in press), and so two 0.5 liter subsamples of Contexts 3 and 23 were wet-sorted for assessment (Kenward et al. 1980). These two contexts were chosen because they represented the most likely deposit types that may have contained uncarbonized material, with Context 3 composed of peat/turf ash and Context 23 composed of a wet, organic, and ashy midden. No uncarbonized material was recovered; therefore, all the samples were wet-sieved and dried.

All plant macrofossil identifications were checked against the botanical literature (Long 1929; Beijerinck 1947; Berggren 1969; 1981; Schweingruber 1990; Anderburg 1994) and modern reference material from collections in Geography and Archaeology at the University of Edinburgh. Nomenclature follows Stace (1994), with ecological information taken from Grime et al. (1988), Clapham et al. (1989), Stace (1994), and Fosaa (2000; 2001). The condition for each cereal grain was recorded to assess the preservation of the sample and phase assemblages, following the index devised by Hubbard and al Azm (1990). The identification criteria for the wild seeds were based on those outlined by van der Veen (1992), with the grasses (Poaceae undiff.) and sedges (Carex spp.) differentiated only as large/ medium/small and biconvex/trigonous, respectively. Each seed was given a count of one, even if broken, except for those large fragments that were clearly from the same seed (following van der Veen 1992). Other miscellaneous plant parts, such as heather leaf fragments, 
were given a fragment count rather than a quantifiable count due to multiple fragmentation (cf. Dickson 1994). The charcoal fragments were generally identified to genus, with the number of fragments and weight in each sample for each genus recorded. The fragments were also categorized into roundwood or timber and the number of rings noted. Other miscellaneous observations, such as bore-holes or vitrification, were noted when appropriate.

A subsample of approximately 0.1 liters was taken from each bulk sample to help assess site formation processes and ecofact taphonomy. Three basic sedimentary tests were undertaken: (1) organic content as indicated by percentage of weight loss on ignition at $550^{\circ} \mathrm{C}$ for four hours (following Dean 1974; Heiri et al. 2001); (2) soil pH using a Fisherbrand Hydrus $100 \mathrm{pH}$ meter to measure c. $20 \mathrm{~g}$ of wet soil in $50 \mathrm{~g}$ of distilled water (following Hodgson 1976); (3) basic mineral magnetic parameters of mass-specific magnetic susceptibility $(\chi)$ and frequency dependent magnetic susceptibility ( $\kappa f d \%)$ using an MS2 Bartington system on air-dried soil (following Dearing 1994).

All digital records and zooarchaeological, archaeobotanical, and geoarchaeological samples will be permanently curated at the Faroese National Museum.

\section{Results and Discussion}

\section{Excavation results}

The excavated cultural layers contained concentrations of burned peat/turf and associated ash, firecracked stone, and well-preserved bone and shell that were separated by sand layers and thin brown humified horizons. The stratigraphy, observed in both plan (Fig. 2) and profile (Fig. 3), suggested a long process of successive and repeated dumps of refuse outside of small walls, interspersed with periods of rapid sand deposit and periods of stabilized vegetation surface. A number of these wall lines were revealed (cf. Context 9) and consisted of low double- or triple-coursed features up to $0.5 \mathrm{~m}$ high. These have been interpreted as the equivalent of farmyard walls that perhaps were topped by turf, though no turf collapse was evident. Therefore, at this stage of the excavations, the excavated material appeared to represent the remains of a farm mound, a feature commonly associated with Norse settlements across the North Atlantic, consisting of material discarded over a number of centuries from structures upslope of the eroding edge, such as the late Norse rectilinear structure revealed in the 2004 excavations.

Table 2 presents the sedimentary results in order from top to bottom of the main section illustrated in Figure 3. The $\mathrm{pH}$ throughout the section was neutral to slightly alkaline, and the organic content relatively low, resulting in the preservation of the bone and shell assemblage in the freely drained sandy matrix. The neutral $\mathrm{pH}$ of the soil derived from the mixed fluvio-glacial sands and degraded calcareous shell that composed the matrix. This soil preservation system was significantly different from other sites recently excavated across the Faroes, such as Toftanes (Stummann Hansen 1993; Edwards et al. 1998; Vickers in press) and Argisbrekka (Mahler 1993; Malmros 1990; 1994). These sites were found in the widespread peaty and podsolized wet and acidic soils that represent the common soil type of the Faroes, in which bone and shell are very poorly preserved. Conversely, uncarbonized plant macrofossil and insect preservation was good on these sites but lacking at 
Undir Junkarinsfløtti. The worst preserved shell and bone were recovered from the lowest three contexts $(23,24$, and 28$)$ where semidissolved and amalgamated "bone mush" was observed. These layers were the wettest excavated on the site, being just above the underlying minerogenic soil and glacial subsoil and within the seasonally fluctuating water table, and had the highest organic content, which further aided the retention of moisture.

\begin{tabular}{|c|c|c|c|c|c|c|c|}
\hline Context & $\begin{array}{c}\text { Organic } \\
\text { content } \\
(\%)\end{array}$ & $\begin{array}{c}\chi \\
\left(10^{-8} \mathrm{~m}^{3} \mathrm{~kg}^{-1}\right)\end{array}$ & $\kappa \mathrm{fd} \%$ & $\mathrm{pH}$ & Grain/liter & $\begin{array}{c}\text { Quantifiable } \\
\text { component/liter }\end{array}$ & $\begin{array}{l}\text { Burned } \\
\text { peat-turf } \\
(\mathrm{g}) / \text { liter }\end{array}$ \\
\hline 2 & 1.9 & 0.7 & 0.8 & 7.54 & 0.0 & 0.0 & 0 \\
\hline 3 & 1.8 & 8.5 & 1.3 & 6.54 & 0.6 & 4.6 & 4.1 \\
\hline 5 & 1.5 & 0.3 & 1.3 & 5.69 & 0.2 & 0.5 & 0.2 \\
\hline 6 & 1.5 & 7.3 & 1.5 & 6.65 & 0.9 & 1.2 & 0.2 \\
\hline 7 & 2.5 & 7.0 & 1 & 7.22 & 0.2 & 1.1 & 0.5 \\
\hline 8 & 2.4 & 6.8 & 1.1 & 8.49 & 0.2 & 1.1 & 0.9 \\
\hline 14 & 7.7 & 8.6 & 3.9 & 8.48 & 0.3 & 2.7 & 27.4 \\
\hline 15 & 2.4 & 7.0 & 0.9 & 7.4 & 0.4 & 0.9 & 0.6 \\
\hline 16 & 2.2 & 7.1 & 1.2 & 8.49 & 0.6 & 1.2 & 0.5 \\
\hline 17 & 2.1 & 7.2 & 1.8 & 7.2 & 0.6 & 0.9 & 1.1 \\
\hline 18 & 1.8 & 7.1 & 2 & 8.64 & 0.1 & 1.0 & 1.2 \\
\hline 19 & 2.0 & 6.9 & 2.1 & 8.73 & 0.3 & 0.6 & 0.9 \\
\hline 20 & 2.4 & 6.9 & 1 & 8.59 & 9.8 & 10.1 & 0.5 \\
\hline 21 & 2.1 & 5.7 & 1.4 & 8.45 & 0.1 & 0.5 & 0.1 \\
\hline 22 & 3.0 & 6.7 & 0.8 & 8.1 & 2.0 & 2.5 & 2.1 \\
\hline 23 & 11.6 & 7.9 & 3.2 & 8.53 & 3.5 & 4.4 & 7.0 \\
\hline 24 & 10.1 & 7.9 & 0 & 7.07 & 1.2 & 2.3 & 0.9 \\
\hline 28 & 10.4 & 8.2 & 2.7 & 7 & 0.5 & 5.5 & 24.3 \\
\hline
\end{tabular}

Magnetic susceptibility $(\chi)$ was relatively high throughout the section, a function of both the mineralogy of the re-deposited offshore fluvioglacial material that composed the sand (Rasmussen 1982) and input of burned and ashy material from peat and turf that is characteristic of the middens in the North Atlantic islands (cf. Peters et al. 2001; 2004). High concentrations of burned peat and turf and the presence of carbonized plant macrofossils were recovered from the sampled layers with observed signs of burned material and ash and high $\chi$ values (Table 2), suggesting the principal taphonomic pathway was from domestic hearths and fires to sampled middens for the archaeobotanical remains. Detailed mineral magnetic and soil micromorphological analysis of the sampled layers is ongoing to test this hypothesis, with results discussed elsewhere. The carbonization of plant material in hearths burning turf and peat results in very poor preservation of plant macrofossils (cf. Church and Peters 2004), demonstrated by the poor level of grain preservation of the site assemblage, with over $50 \%$ of the grain in the worst preservation class (see Table 3 ). 
Table 3. Archaeobotanical remains from Undir Junkarinsfløtti

\begin{tabular}{|c|c|c|c|c|c|}
\hline & Phase & UJF1 & UJF2 & UJF3 & $\begin{array}{l}\text { Total } \\
\text { site }\end{array}$ \\
\hline & Number of samples in phase & 5 & 6 & 7 & 18 \\
\hline & $\begin{array}{l}\text { Total volume of samples } \\
\text { (liters) }\end{array}$ & 44 & 63 & 58.5 & 165.5 \\
\hline \multicolumn{6}{|l|}{ Charcoal } \\
\hline Betula sp. timber fragment & Birch timber fragment & $7 F(1.02)$ & & & $7 \mathrm{~F}(1.02)$ \\
\hline $\begin{array}{l}\text { Calluna vulgaris (L.) round- } \\
\text { wood }(2-4 \mathrm{~mm})\end{array}$ & $\begin{array}{l}\text { Ling heather roundwood } \\
\text { fragment }\end{array}$ & present & present & present & present \\
\hline $\begin{array}{l}\text { Calluna vulgaris (L.) round- } \\
\text { wood (>4 mm) }\end{array}$ & $\begin{array}{l}\text { Ling heather roundwood } \\
\text { fragment }\end{array}$ & $1 \mathrm{~F}(0.04)$ & & & $1 \mathrm{~F}(0.04)$ \\
\hline $\begin{array}{l}\text { Coniferae indet. timber } \\
\text { fragment }\end{array}$ & Conifer timber fragment & & $2 \mathrm{~F}(0.03)$ & & $2 \mathrm{~F}(0.03)$ \\
\hline Juniperis sp. roundwood & $\begin{array}{l}\text { Juniper roundwood } \\
\text { fragment }\end{array}$ & $1 \mathrm{~F}(0.03)$ & & & $1 \mathrm{~F}(0.03)$ \\
\hline Larix sp. timber fragment & Larch timber fragment & $6 \mathrm{~F}(0.15)$ & $2 \mathrm{~F}(0.04)$ & $2 \mathrm{~F}(0.05)$ & $10 \mathrm{~F}(0.24)$ \\
\hline Picea sp. timber fragment & Spruce timber fragment & $1 F(0.02)$ & & & $1 \mathrm{~F}(0.02)$ \\
\hline Pinus sp. timber fragment & Pine timber fragment & $1 F(0.03)$ & & & $1 \mathrm{~F}(0.03)$ \\
\hline Quercus sp. timber fragment & Oak timber fragment & $4 \mathrm{~F}(0.09)$ & & & $4 \mathrm{~F}(0.09)$ \\
\hline Burned peat/turf fragments & Burned peat/turf fragments & $128.6 \mathrm{~g}$ & $53.2 \mathrm{~g}$ & $154.5 \mathrm{~g}$ & $336.3 \mathrm{~g}$ \\
\hline \multicolumn{6}{|l|}{ Grain } \\
\hline Hordeum sp. (C) & Barley grain & 17 & 30 & 7 & 54 \\
\hline Hordeum hulled (C) & Hulled barley grain & 13 & 12 & 3 & 28 \\
\hline $\begin{array}{l}\text { Hordeum hulled } \\
\text { symmetric (C) }\end{array}$ & Hulled barley straight grain & 3 & 1 & 3 & 7 \\
\hline $\begin{array}{l}\text { Hordeum hulled } \\
\text { asymmetric }(\mathrm{C})\end{array}$ & Hulled barley twisted grain & 7 & 5 & & 12 \\
\hline Avena sp. (C) & Oat grain & 1 & 1 & & 2 \\
\hline \multirow[t]{2}{*}{ Cereal indeterminate $(C)$} & Cereal grain & 32 & 51 & 8 & 91 \\
\hline & Total grain & 73 & 100 & 21 & 194 \\
\hline \multicolumn{6}{|l|}{ Chaff } \\
\hline Hordeum sp. (RI) & Barley rachis internode & & 1 & 2 & 3 \\
\hline H. vulgare L. (RI) & $\begin{array}{l}\text { Six row barely rachis } \\
\text { internode }\end{array}$ & 1 & & & 1 \\
\hline $\begin{array}{l}\text { Cereal/monocotyledon } \\
(>2 \mathrm{~mm})(\mathrm{CN})\end{array}$ & $\begin{array}{l}\text { Cereal/monocotyledon } \\
\text { culm node }\end{array}$ & 1 & & & 1 \\
\hline \multirow[t]{2}{*}{$\begin{array}{l}\text { Cereal/monocotyledon } \\
(>2 \mathrm{~mm})(\mathrm{CB})\end{array}$} & $\begin{array}{l}\text { Cereal/monocotyledon } \\
\text { culm base }\end{array}$ & & & 1 & 1 \\
\hline & Total chaff & 2 & 1 & 3 & 6 \\
\hline \multicolumn{6}{|l|}{ Wild plants } \\
\hline Brassica/Sinapis spp. (S) & Cabbage/Mustard & 1 & & & 1 \\
\hline Calluna vulgaris (L.) Hull. (LF) & Ling heather & & & $2 \mathrm{LF}$ & $2 \mathrm{LF}$ \\
\hline Carex spp. (trigonous) $(\mathrm{N})$ & Sedge & 3 & 1 & & 4 \\
\hline Danthonia decumbens L. (C) & Heath-grass & & & 1 & 1 \\
\hline Montia fontana L. (S) & Blinks & 1 & & 2 & 3 \\
\hline Poaceae undiff. (medium) (C) & Grass & & 1 & 1 & 2 \\
\hline Poaceae undiff. (small) (C) & Grass & 1 & 2 & 1 & 4 \\
\hline Polygonum spp. (N) & Knotgrass & 1 & & & 1 \\
\hline Ranunculus repens L. (A) & Creeping buttercup & & & 6 & 6 \\
\hline Ranunculus spp. (A) & Buttercup & 1 & & 1 & 2 \\
\hline Rumex acetosa L. (N) & Common sorrel & 1 & & 1 & 2 \\
\hline
\end{tabular}


Table 3. Continued

\begin{tabular}{|c|c|c|c|c|c|}
\hline & Phase & UJF1 & UJF2 & UJF3 & $\begin{array}{c}\text { Total } \\
\text { site }\end{array}$ \\
\hline Rumex crispus/obtusifolius L. (N) & Curled dock & 2 & & 5 & 8 \\
\hline Rumex spp. (N) & Dock & 1 & & 1 & 2 \\
\hline Spergula arensis L. (S) & Corn-spurrey & 1 & & 9 & 10 \\
\hline Stellaria media L. (S) & Common chickweed & 6 & 10 & 7 & 23 \\
\hline Viola sp. (S) & Violet & 1 & & & 1 \\
\hline $\begin{array}{l}\text { Cereal/monocotyledon } \\
(<2 \mathrm{~mm})(\mathrm{CN})\end{array}$ & $\begin{array}{l}\text { Cereal/monocotyledon } \\
\text { culm node }\end{array}$ & 3 & 3 & 2 & 8 \\
\hline $\begin{array}{l}\text { Cereal/monocotyledon } \\
(<2 \mathrm{~mm})(\mathrm{CB})\end{array}$ & $\begin{array}{l}\text { Cereal/monocotyledon } \\
\text { culm base }\end{array}$ & 4 & 5 & 2 & 11 \\
\hline Indeterminate $(>2 \mathrm{~mm})(\mathrm{R})$ & indeterminate rhizome & 1 & & 2 & 3 \\
\hline Indeterminate $(<2 \mathrm{~mm})(\mathrm{R})$ & Indeterminate rhizome & 1 & 1 & 4 & 6 \\
\hline $\begin{array}{l}\text { Indeterminate (trigonous) } \\
\quad(\mathrm{S} / \mathrm{F})\end{array}$ & $\begin{array}{l}\text { Indeterminate trigonous } \\
\text { seed/fruit }\end{array}$ & 1 & & 1 & 2 \\
\hline $\begin{array}{l}\text { Indeterminate pericarp } \\
\text { fragment }(\mathrm{P})\end{array}$ & $\begin{array}{l}\text { Indeterminate pericarp } \\
\text { fragment }\end{array}$ & & 1 & & 1 \\
\hline $\begin{array}{l}\text { Indeterminate seed/fruit } \\
(\mathrm{S} / \mathrm{F})\end{array}$ & Indeterminate seed/fruit & 8 & 5 & 11 & 24 \\
\hline \multirow[t]{5}{*}{$\begin{array}{l}\text { Moss fragments } \\
\text { (carbonized) (LF) }\end{array}$} & $\begin{array}{l}\text { Moss leaf fragment } \\
\text { (carbonized) }\end{array}$ & & & $1 \mathrm{LF}$ & $1 \mathrm{LF}$ \\
\hline & Total wild & 38 & 30 & 57 & 125 \\
\hline & $\begin{array}{l}\text { Total Quantifiable } \\
\text { Components }\end{array}$ & 113 & 131 & 81 & 325 \\
\hline & Grain/liter & 1.7 & 1.6 & 0.4 & 1.2 \\
\hline & Quantifiable Component/liter & 2.6 & 2.1 & 1.4 & 2.0 \\
\hline \multirow{6}{*}{$\begin{array}{l}\text { Grain preservation } \\
\text { (Hubbard and Al Azm } \\
\text { 1990) }\end{array}$} & $\begin{array}{l}\text { Class } 1 \\
\text { (best preservation-\%) }\end{array}$ & 0 & 0 & 0 & 0 \\
\hline & Class $2(\%)$ & 3 & 3 & 5 & 3 \\
\hline & Class $3(\%)$ & 10 & 5 & 0 & 6 \\
\hline & Class $4(\%)$ & 18 & 12 & 19 & 15 \\
\hline & Class $5(\%)$ & 22 & 18 & 33 & 21 \\
\hline & $\begin{array}{l}\text { Class } 6 \\
\quad \text { (worst preservation-\%) }\end{array}$ & 48 & 62 & 43 & 55 \\
\hline
\end{tabular}

Notes: Key to plant parts: Grain $(C)=$ caryopsis; Chaff $(C B)=$ culm base (greater than $2 \mathrm{~mm}$ in diameter), $(\mathrm{CN})$ $=$ culm node (greater than $2 \mathrm{~mm}$ in diameter $),(\mathrm{RI})=$ rachis internode; Wild plants $(\mathrm{A})=$ achene, $(\mathrm{C})=$ caryopsis, $(\mathrm{F})=$ fruit, $(\mathrm{CB})=$ culm base (less than $2 \mathrm{~mm}$ in diameter), $(\mathrm{CN})=$ culm node (less than $2 \mathrm{~mm}$ in diameter), (LF) $=$ leaf fragment, $(\mathrm{N})=$ nutlet, $(\mathrm{P})=$ pericarp,$(\mathrm{R})=$ rhizome (greater and less than $2 \mathrm{~mm}$ in diameter), $(\mathrm{S})=$ seed. NB: The charcoal is quantified by number of fragments followed by mass in grams within brackets.

A detailed dating strategy was formulated, based on the AMS radiocarbon determinations of single entities of barley (Hordeum sp.) grains, cow (Bos taurus L.), and pig (Sus scrofa L.) bones and common limpet shells (Patella vulgaris L.) at the SUERC radiocarbon laboratory in Scotland. The strategy had three research aims:

1) To date the sequence of midden deposits, with determinations from multiple stacked contexts in order to use Bayesian statistics to refine the chronological precision (cf. Buck et al. 1996). Unfortunately, this was not possible, as nearly all the determinations were of very similar age and calibrated into the 10th to early 13th centuries 
cal. AD radiocarbon plateau. Table 1 presents the radiocarbon determinations obtained from the site and calibrated using OxCal (Bronk Ramsey 2003), expressed at $95 \%$ confidence intervals. Initial analysis of the artifactual assemblage identified a bronze brooch of 10th century AD date recovered from the basal midden deposit (Arge 2001) and hand-built coarse local pottery usually considered to date to the late Viking (c. AD 950-1100) and early medieval (c. AD 1100-1200) periods recovered from the upper portion of the deep cultural deposits excavated in 2000, 2003, and 2004 (cf. Arge 1991; 1997). Scattered shards of 16th-20th century pottery were recovered from the thick amended topsoil (Context 1 ), relating to manuring activity of what had become a set of enclosed pastures at the edge of Sandur village. Therefore, the site was separated into three phases based on the archaeological stratigraphy, radiocarbon dates, and artifacts. UJF1 represented the earliest deposits (Contexts 21 to 28 ) dated to 9th-12th centuries cal. AD, UJF2 included Contexts 15 to 20 dating to 11th-12th centuries cal. AD, and UJF3 included Contexts 3 to 14 and dates to the 11th-13th centuries cal. AD.

2) To establish the first marine reservoir correction factor for the Norse period in the Faroes by pairing terrestrial determinations (carbonized barley grains and cow bones) with marine determinations (limpet) from the same stratigraphic layer (Context 23), an approach successfully employed in Atlantic Scotland by Ascough et al. (2004). The results are discussed elsewhere (Ascough et al. in press).

3) To establish the presence of any significant marine component within the diet of the pigs through examination of the $\delta 13 \mathrm{C}$ values produced during radiocarbon determinations of pig bones. This formed part of an international project investigating piggery practices across the North Atlantic in the Norse and early Medieval periods. It was hypothesized that the pigs may have been kept in sties and fed fish offal, keeping grass fodder for sheep and cattle use over the winter. However, the $\delta 13 \mathrm{C}$ values from the pig bones from Contexts 22 and 23 (Table 1 ) were consistent with values expected of animals feeding exclusively within the terrestrial food web (cf. De Niro 1985; Gupta and Polach 1985; Koch et al. 1994; Arneborg et al. 1999), and so this hypothesis was rejected.

\section{Animals and marine resources at Undir Junkarinsfløtti}

The substantial, well-preserved archaeofauna collected in 2003 provided the first zooarchaeological evidence for past economic strategies in Viking age and early Medieval Faroes (for full technical report see McGovern et al. 2004). Additional large animal bone collections are now under study from the 2004 excavation season. However, enough material has been analyzed to allow a first look at major patterns in the zooarchaeology of this key site and for some comparisons to be drawn with contemporary collections from Northern Iceland and Greenland, excavated and analyzed by the same team. Table 4 summarizes the animal bone collection from the three major phases. 
Table 4. Summary archaeofauna and NISP from Undir Junkarinsfløtti

\begin{tabular}{|c|c|c|c|c|}
\hline & UJF1 & UJF2 & UJF3 & Total \\
\hline Cattle (Bos taurus L.) & 18 & 14 & 25 & 57 \\
\hline Dog (Canis familiaris L.) & & & 1 & 1 \\
\hline Pig (Sus scrofa L.) & 13 & 20 & 43 & 76 \\
\hline Sheep (Ovis aries L.) & 4 & 12 & 30 & 46 \\
\hline Goat (Capra hircus L.) & & 1 & & 1 \\
\hline Caprine & 41 & 71 & 142 & 254 \\
\hline Total Domestic Mammals & 76 & 118 & 241 & 435 \\
\hline Whale (Cetacea sp.) & 1 & 2 & & 3 \\
\hline Grey Seal (Halichoerus gryphus L.) & & & 5 & 5 \\
\hline Large Seal (probably Grey Seal) & 1 & 2 & 1 & 4 \\
\hline Small Seal (probably Harbor Seal, Phoca vitulina L.) & & 1 & & 1 \\
\hline Seal (Phocid sp.) & & 3 & 1 & 4 \\
\hline Total Whales/Seals & 2 & 8 & 7 & 17 \\
\hline Puffin (Fratercula arctica L.) & 451 & 459 & 995 & 1905 \\
\hline Guillemot (Uria lomvia L.) & 2 & & 4 & 6 \\
\hline Black Guillemot (Cepphus grille L.) & 1 & & & 1 \\
\hline Murre/Guillemot (Uria sp.) & 116 & 51 & 76 & 243 \\
\hline Razorbill (Alca torda L.) & 6 & 9 & 5 & 20 \\
\hline Duck (Anatidae sp.) & & & 2 & 2 \\
\hline Eider duck (Somateria molissimus L.) & & & 1 & 1 \\
\hline Manx shearwater (Puffinus puffinus L.) & 1 & 4 & 7 & 12 \\
\hline Gannet (Sula bassana L.) & & 2 & 1 & 3 \\
\hline Shag (Phalacrocorax aristotelis L.) & 2 & 4 & 8 & 14 \\
\hline Gull (Laridae sp.) & 1 & 1 & 2 & 4 \\
\hline Goose (possibly domestic: Anseridae sp.) & & 7 & 7 & 14 \\
\hline Bird sp. & 488 & 626 & 1044 & 2158 \\
\hline Total Birds & 1068 & 1167 & 2148 & 4383 \\
\hline Gadid Fish & & & & \\
\hline Atlantic Cod (Gadus morhua L.) & 592 & 206 & 391 & 1189 \\
\hline Ling (Molva molva L.) & & & 7 & 7 \\
\hline Cusk (Brosme brosme L.) & 14 & 13 & 42 & 69 \\
\hline Cod family (Gadidae) & 260 & 48 & 114 & 422 \\
\hline Salmonid fish & & & & \\
\hline Salmon family (Salmonidae) & & 3 & & 3 \\
\hline Trout (Salmo trutta L.) & 3 & & 1 & 4 \\
\hline Flatfish & & & & \\
\hline Flatfish (Pleuronectiformes sp.) & & 7 & 2 & 9 \\
\hline Atlantic Halibut (Hippoglossus hippoglossus L.) & 3 & & & 3 \\
\hline Other Fish & & & & \\
\hline Skates (Rajidae undiff.) & & 7 & 2 & 9 \\
\hline Wolf fish (Anarchiradidae undiff.) & & 2 & & 2 \\
\hline Brill (Scapthalmidae undiff.) & 2 & 1 & & 3 \\
\hline Rockfish (Sebastidae undiff.) & & & 6 & 6 \\
\hline Sculpin (Cottidae undiff.) & & 3 & 2 & 5 \\
\hline Fish indeterminate & 1526 & 283 & 590 & 2399 \\
\hline Total fish & 2400 & 573 & 1157 & 4130 \\
\hline
\end{tabular}




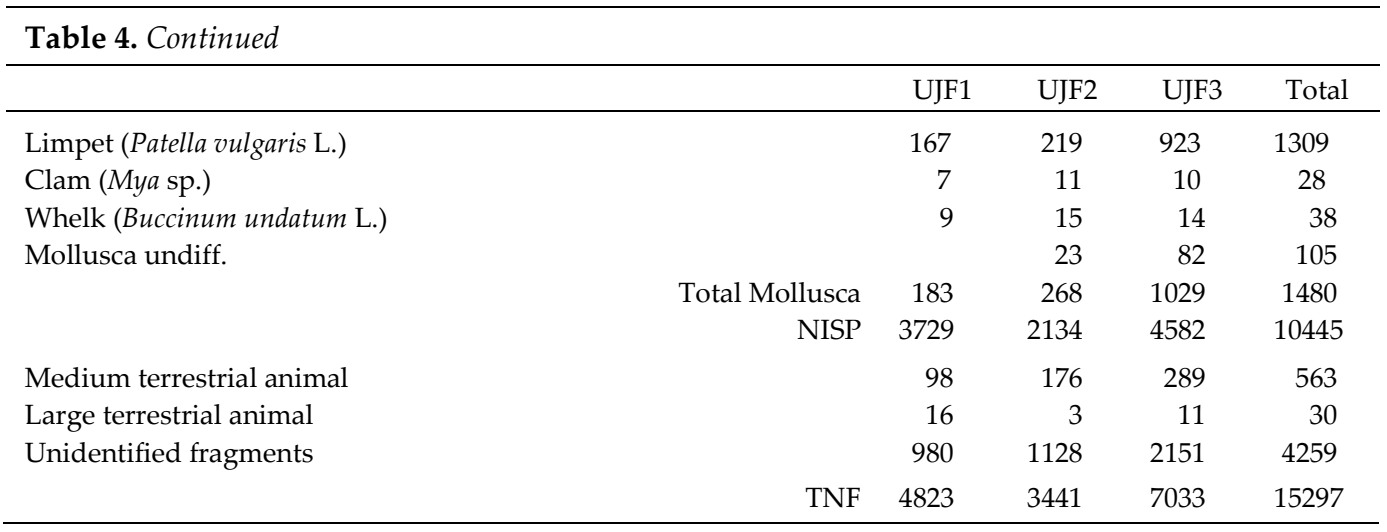

Figure 4 compares the distribution of major taxa in the three phases of the archaeofauna. In each case, bones of domestic and marine mammals made up a fairly minor portion of the collection (2-5\%) compared to the amount of bird, fish, and shellfish remains recovered. Birds (mainly puffin, Fratercula arctica L.) came to outnumber fish bones in the upper layers, while shellfish (mainly common limpets, Patella vulgaris L.) also increased in the upper layers. These patterns showed some similarities with Landnám sequences from Iceland and Greenland but were unique in many respects. Figure 5 places the three major contexts from Junkarinsfløtti in comparison with contemporary archaeofauna from Iceland and Greenland. In Iceland, many Landnám era collections were also dominated by wild species, and in late Medieval-early modern times marine fish again played a major role in both subsistence and trade (Amundsen et al. in press). However, even at first settlement (Tjarnargata 4, Herjolfsdalur, Sveigakot), domestic mammal bone percentages were normally $15 \%$ or above and in the 10 th-11th century AD rose to $40-70 \%$ of the total collection (Sveigakot, Hofstaðir, Hrísheimar, Selhagi, Svalbarð) (Fig. 5). While the Greenlandic Norse colonists (site W48, site W51, site E17a, GUS [Gården Under Sandet]) may have encountered significantly harsher conditions in their 11th century AD Landnám, their archaeofauna was still composed of 15-40\% domesticates (McGovern 1985; Outram 1999; 2003). 


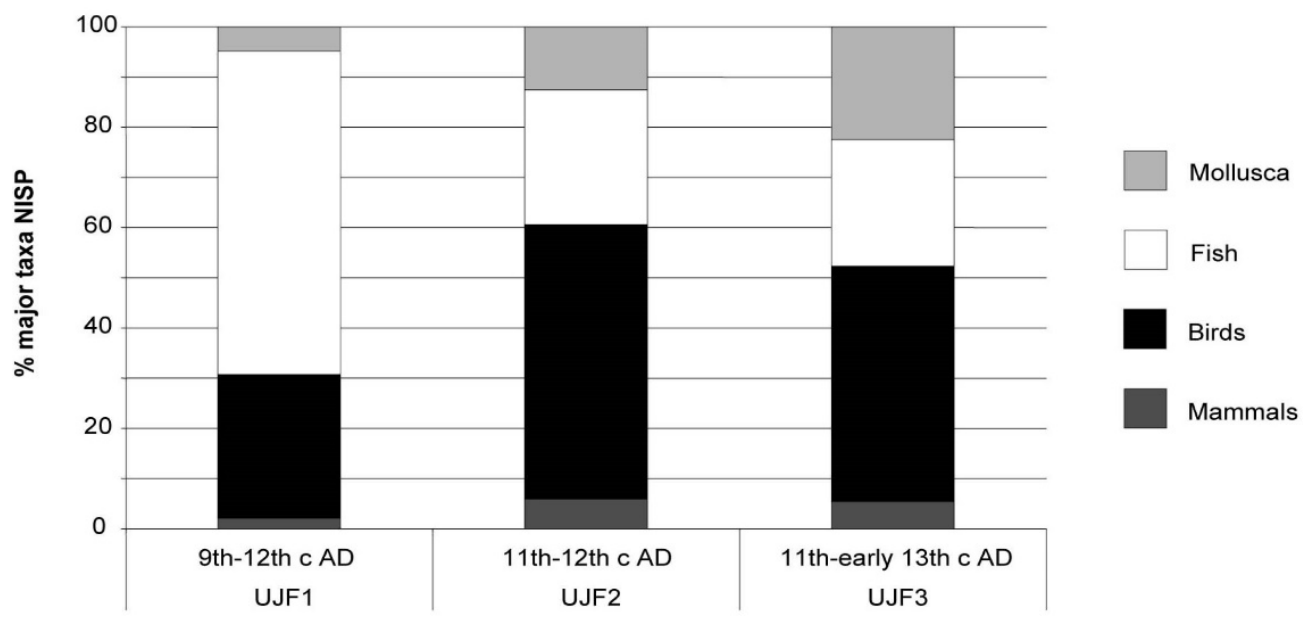

Figure 4. Distribution of major faunal taxa in the three phases from Undir Junkarinsfløtti (UJF). See Table 4 for NISP.

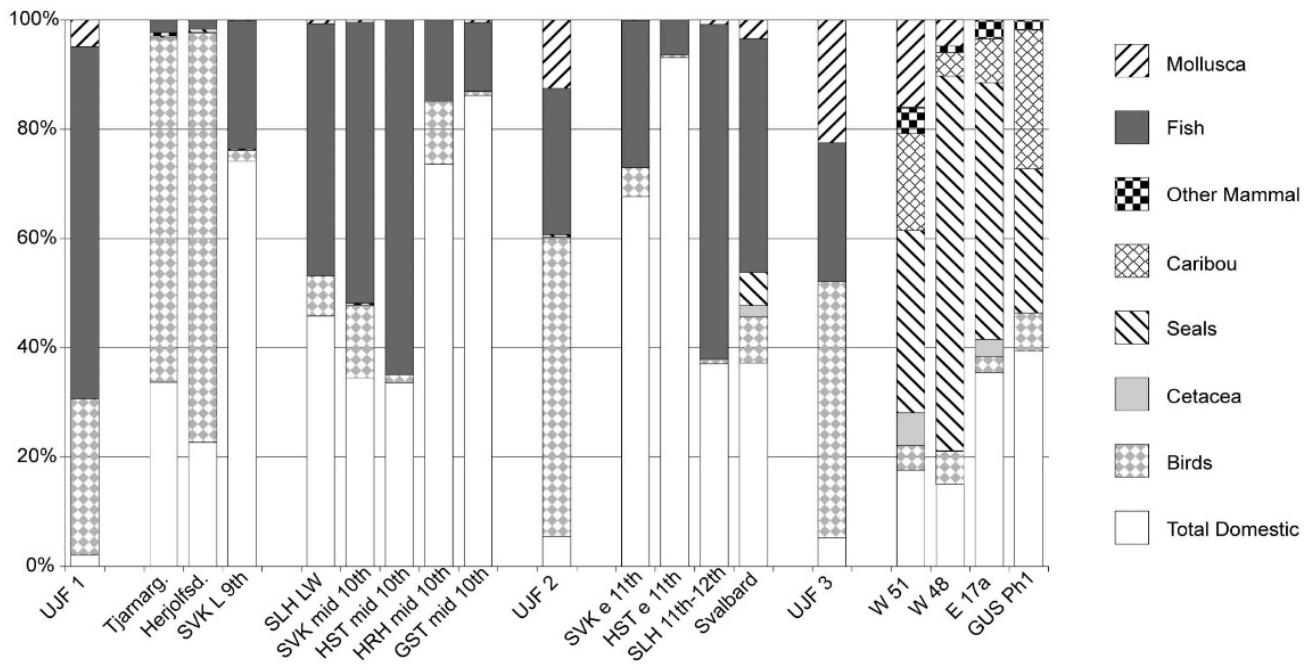

Figure 5. The archaeofauna of Undir Junkarinsfløtti in comparison with contemporary archaeofauna from Iceland and Greenland. Abbreviations and zooarchaeological references as follows: Faroes-UJF1, UJF2, and UJF3 = Undir Junkarinsfløtti phases; IcelandTjarnarg. = Tjarnargata 4, Herjolfsd. = Herjolfsdalur (Amorosi 1996), SVK L 9th $=$ Sveigakot late 9th century AD phases, SVK mid 10th = Sveigakot mid 10th century AD phase, SVK e 11th = Sveigakot early 11th century AD phase, SLH LW = Selhagi Lower 9th-10th century AD phase, SLH 11th-12th = Selhagi 11th-12th century AD phase, HST mid 10th $=$ Hofstaðir mid 10th century AD phase, HST e 11th = Hofstaðir early 11th century AD phase, HRH mid 10th = Hrísheimar mid 10th century AD phase (McGovern et al. 2001), GST mid 10th = Granastaðir mid 10th (Einarsson 1994), Svalbarð = Svalbarð (Amorosi 1992); Greenland - W 51 = Site W 51 (McGovern et al. 1996), W 48 = site W 48 (McGovern et al. 1983), E 17a = Site E 17a (McGovern et al. 1993), GUS Ph1 = Gården Under Sandet Phase 1 (Enghoff 2003). 
One of the most striking aspects of the Undir Junkarinsfløtti archaeofauna was the large proportion of bird bones in all phases (Table 4). Puffins and related alcids (guillemot, black guillemot, and razorbill) constituted the overwhelming majority of these remains, and most of the unidentified bird bones could have been small alcid from their size. The presence of Manx shearwater bones suggested the exploitation of nesting cliffs, a practice widespread in modern times in Faroes. Goose (Anser sp.) bones are notoriously difficult to positively identify as wild or domestic (Benecke 1993), but it is known that domestic geese were part of the Viking age farmyard (Hutton-Macdonald et al. 1993), and it is possible that these bones, one of which contains medullary bone characteristic of egg laying females, came from domestic animals. One puffin bone came from a fledgling chick, again suggesting exploitation of nesting colonies.

The very high percentages of bird bones in the Junkarinsfløtti archaeofauna had parallels in archaeofauna from southern Iceland (McGovern et al. 2001), where predation upon sea bird colonies probably helped sustain settlers until imported stock could multiply. After the initial Landnám, birds provided a fairly minor supplement to fishing and domestic mammal products in Iceland. In Greenland, sea birds were also taken regularly, but seals and caribou were far more important wild resources. Only at Junkarinsfløtti was there such a definite pattern of sustained, and clearly sustainable, use of wild bird colonies. Issues of biogeography, marine productivity, and social management of a wild resource all require further investigation. We can now state that the Faroese remained dependent upon bird resources, especially puffins, far longer, and to a far greater degree than any of the other Viking age settlers of the North Atlantic islands, even if we cannot yet explain how and why.

Figure 6 presents the changing proportions of domestic mammal bones from the 2003 Junkarinsfløtti collection. The relative proportion of cattle decreased between the earliest and subsequent phases, a pattern widely observed in most North Atlantic Landnám sites where early hopes for high status cattle rich holdings may have been regularly frustrated by the realities of island farming (McGovern et al. 2001). "Caprine" refers to the many bones that may have come from either sheep or goat but could not be further speciated. With the exception of a single bone in UJF2, all the identified caprines were in fact sheep. In Landnám-era Iceland and Greenland, goats were far more common. In Iceland goats declined to their modern "trace" levels only in the early 13th century AD (McGovern et al. 2001), and in Greenland goats remained nearly as common as sheep in many collections down to the end of the colony in the 14th-15th century AD (cf. McGovern et al. 1983; 1993; 1996; Enghoff 2003). As goats are more effective at metabolizing twigs and leaves than sheep, their early reduction in the Faroes may have been tied to the absence of significant woodland. 


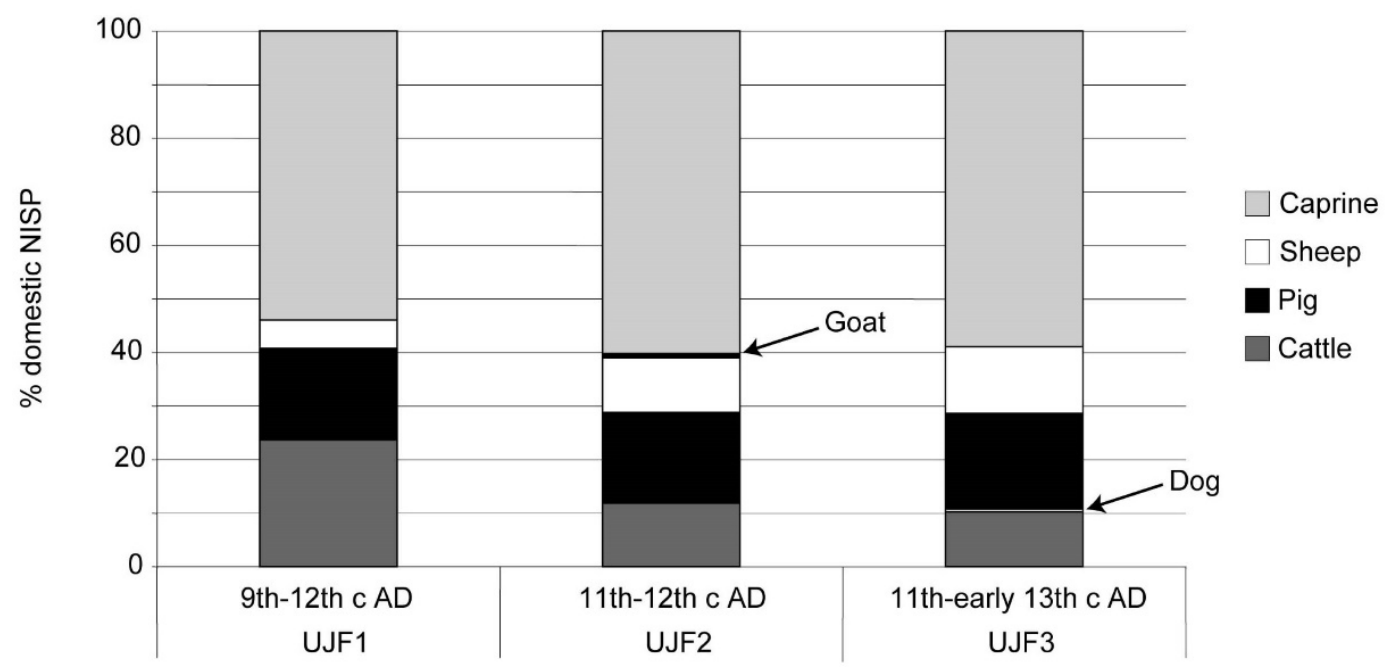

Figure 6. Changing proportions of domestic mammal bones in the three phases from Undir Junkarinsfløtti (UJF). See Table 4 for NISP.

The presence of substantial numbers of pigs was also commonplace in Landnám sites in Greenland (cf. Enghoff 2003) and Iceland (McGovern et al. 2001), but pigs rarely survived as a major element in the domestic economy much beyond the mid 11th century AD in either of these islands. Pigs became extinct in the Faroes later in the Middle Ages (Arge in press), with a few place names reflecting earlier piggery around the area of Litlavatn (Fig. 1: see Lawson et al. in press for further discussion). In Arctic Norway, however, pigs remained economically important into early modern times and never became entirely extinct (Perdikaris 1999; Amundsen 2004). Pigs reproduce rapidly and have been favored "Landnám" domesticates in both Atlantic and Pacific islands, but economic pig keeping requires either substantial unmanaged woods or marshland for free ranging pannage or some source of feed for penned sty kept animals (Ward and Mainland 1999). In Medieval England, many communities had already converted from open pannage to sty piggery by the 1086 Domesday survey, with improving monasteries taking a lead in raising legumes mainly as pig fodder (Biddick 1984). The isotopic data from the pig radiocarbon samples (Table 1) indicated that they fed on terrestrial material, not marine-based feed such as fish offal. The actual strategy for pig husbandry followed in Viking age and early Medieval Faroes, and the reasons for the abandonment of pig keeping after the 13th century remain topics for further collaborative investigation.

While sample sizes of intact tooth rows and long bone epiphyses were too small for statistical analysis, the large number of newborn (neonatal) cattle bones (20-50\% of all cattle) strongly suggested the same sort of dairy economy already documented in Greenland, Iceland, and Atlantic Scotland (cf. McGovern 1985; McGovern et al. 2001; Bond 2002). Sheep and caprine bones were too rare to even tentatively reconstruct a management strategy.

Marine resources were also very common in all three phases. Molluscs recovered were mainly the common limpet (Patella vulgaris L.), which retained its dominance even if only complete specimens were counted (Table 4). Some fragments of a clam and of whelk were 
also present but as trace species. As the anthropogenic status of any common shellfish should be questioned in a beachfront setting, it is interesting to report that whenever the complete shell of the limpet survived it invariably showed a notch left by a pry-stick used by a human collector to remove them from rocks. These were therefore almost entirely deliberately gathered shellfish, either as human food or for use as bait.

Whale and seal bones were present but rare in all three phases. The whalebone specimens were probably tool-making debris, as all the fragments were relatively small and all showed cut marks and one was sawn. Species identification was not possible from these fragments, nor was it possible to be certain if the bones came from great whales (such as black right whale, Eubalaena glacialis L., or humpback, Balaenoptera musculus L.) or from smaller toothed whales and porpoise. Seal bones included some elements that could be positively identified as grey seal (Halichoerus gryphus L.) as well as some bones of smaller seals, which were almost certainly from harbor seal (Phoca vitulina L.), including one from a newborn animal.

Identified fish bones included rays, salmon, trout, and flatfish, but the great majority were from the cod (gadid) family (Table 4). While a few deepwater ling and cusk were present, the great majority of the gadids were Atlantic cod (Gadus morhua L.). Following Wheeler and Jones (1989), it was possible to reconstruct live length of the Undir Junkarinsfløtti cod based on measurements of the dentary and premaxillary bones (Fig. 7). Fish between 60 and $110 \mathrm{~cm}$ in live length were best suited for the preparation of air-dried stockfish, while smaller fish $(40-70 \mathrm{~cm})$ were more typically used for the production of a flat-dried product similar to modern Norwegian klippfisk (Bigelow 1985; Cerón-Carrasco 1998; Perdikaris 1999; Barrett et al. 2001; Perdikaris et al. 2002; Amundsen 2004). While sample size was modest for gadids ( $\mathrm{n}$ for the site $=1687$ ), it was apparent that most of the cod landed at Junkarinsfløtti were too small to be effectively air dried as stockfish. Cod skeletal element distribution in the current sample indicated a high frequency of mouthparts and upper (thoracic and precaudal) vertebrae (usually discarded at fish processing sites) relative to a low frequency of cleithra and thoracic vertebrae (usually exported in the preserved fish product). While more analysis on remains recovered from the 2004 season is underway, this pattern from the 2003 collection raised the issue of a possible production of some sort of preserved fish product at the site during the Norse period. 


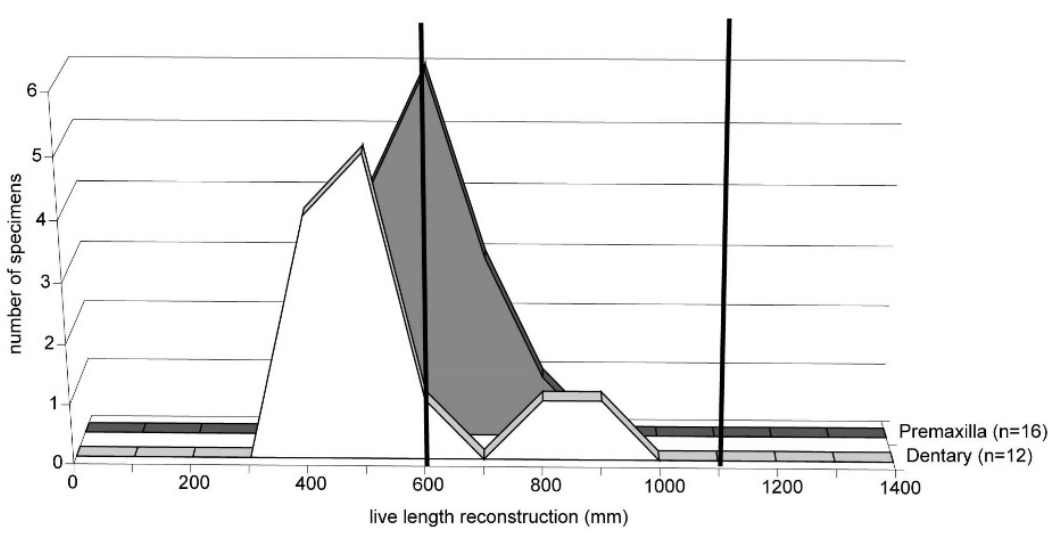

Figure 7. Cod size reconstruction from all phases from Undir Junkarinsfløtti.

\section{The use of plants at Undir Junkarinsfløtti}

Archaeobotanical material from the three phases were very low in concentration and consisted of carbonized plant macrofossils of cereal grains, a little cereal chaff, various plant parts from wild species, a few small pieces of charcoal and abundant fragments of burned peat and turf (Table 3). The abundance of carbonized peat and turf fragments, coupled with the very low concentrations of charcoal, suggested that peat and turf were the primary fuel sources, a hypothesis to be tested by micromorphological analysis of the midden material. Also, some of the wild species, such as ling heather (Calluna vulgaris L. Hull), and small culm bases/rhizomes, could have been introduced by the use of peat and turf as fuel (McLaughlin 1980; Dickson 1994; 1998; Church 2002a) or even from the burning of dung of animals grazing the Faroese outfield (cf. Miller and Smart 1984; Charles 1998). To extract peat from areas of blanket bog such as Lítlavatn and Millum Vatna (see Fig. 1) required planning, social organization, and equipment. The planning involved gathering enough people in the right place at the right points in the year for the cutting, stacking, collecting, and storing of peat. The social organization provided an infrastructure needed to mobilize labor to do the job effectively and also to maintain rights of extraction from an area. Peat procurement was obviously a key component in the Faroese Norse economy, and its extraction would have had an impact on the wider landscape, mobilizing organic-rich runoff into the hydrological system (see Lawson et al. in press). This fuel procurement strategy had been in place for thousands of years within the Atlantic Scottish islands (Church and Peters 2004) since the widespread encroachment of blanket bog from the mid Holocene. However, in Iceland peat and turf became used as the primary fuel source only once birch became scarce following the settlement period, and their use was not uniform across sites, depending on the status and location of the settlement (Simpson et al. 2003).

The cereal remains were dominated by six-row hulled barley (Hordeum vulgare var. vulgare L.), identified by the presence of rachis internodes and the symmetric-asymmetric grain ratio of close to 1:2 for the whole assemblage (following Renfrew 1973). Six-row hulled barley was the staple cereal of the Norse period in the North Atlantic, from Atlantic Scotland (Boyd 1988; Dickson and Dickson 2000) to Iceland (Sveinbjörnsdóttir et al. 2004). A few grains of oat (Avena sp.) were also recovered from the site. These could not be 
identified to species without the preservation of floret bases, and so it was impossible to determine if the oat was the wild or cultivated species and if it was grown in its own right.

It was also an important research question to assess whether the barley was grown in the Faroes or was imported, as recorded in the later Medieval and modern times in the Faroes. This question was particularly pertinent when comparing cereal concentrations from Junkarinsfløtti and midden contexts from three contemporary Norse period sites in the Western Isles of Scotland (Table 5), the homeland of some of the Norse settlers (Debes 1993). At the settlement sites of Barvas (Cowie 1987), Bostadh (Neighbour and Burgess 1997), and Galson (Neighbour and Church 2001), local cultivation was indicated by proxies independent of the archaeobotanical remains, such as pollen analysis of the surrounding landscape and the presence of artifacts for cereal cultivation (Church 2002a). The cereal remains from each Western Isles site were similar, with grain in high concentrations (grain/ liter averages from 7.2 to 27.7) and small amounts of chaff present (straw culm nodes and bases, barley rachis internodes, and oat floret bases). It was probable that at least subsistencebased cereal cultivation was undertaken at each of these settlements. However, the assemblage from Junkarinsfløtti was different, with much lower concentrations of grain (average 1.2 grains/liter), trace levels of straw-sized culm nodes/bases and barley rachis internodes, and no oat floret bases. Does this mean that cereal cultivation was not practiced in the area and rather the small amounts of grain were imported? Again, independent proxies were analyzed. Figure 8 presents summary taxa from a core taken by Lawson et al. (in press) from a small lake called Gróthúsvatn, approximately $1 \mathrm{~km}$ west of Undir Junkarinsfløtti (Fig. 1). The impact of landnám was seen with the increased frequency of ribwort plantain (Plantago lanceolata L.) and microcharcoal, coupled with the first appearance of barley type pollen. This indicated that local barley cultivation was in evidence from the time of settlement. Therefore local cultivation was likely but arguably on a smaller scale and of less importance to the overall economy than established practices in the areas inhabited throughout the Holocene in the eastern North Atlantic, such as the Western Isles of Scotland.

\begin{tabular}{|c|c|c|c|c|}
\hline Site & UJF & Barvas & Bostadh & Galson \\
\hline Number of midden samples & 18 & 27 & 11 & 10 \\
\hline Average Quantifiable Component/liter & 2.0 & 9.8 & 7.8 & 34.5 \\
\hline Culm nodes/bases & trace & present & frequent & frequent \\
\hline Barley rachis & trace & present & trace & present \\
\hline Oat floret bases & none & trace & trace & trace \\
\hline Number of identifiable cereal grains & 103 & 1694 & 1533 & 1764 \\
\hline Average grain/liter & 1.2 & 8.9 & 7.2 & 27.7 \\
\hline Barley (\%) & 98 & 71 & 72 & 79 \\
\hline Oat $(\%)$ & 2 & 27 & 27 & 20 \\
\hline Flax $(\%)$ & none & 2 & 1 & 1 \\
\hline Rye (\%) & none & none & trace & trace \\
\hline Wheat (\%) & none & none & trace & trace \\
\hline
\end{tabular}




\section{Gróthúsvatn}

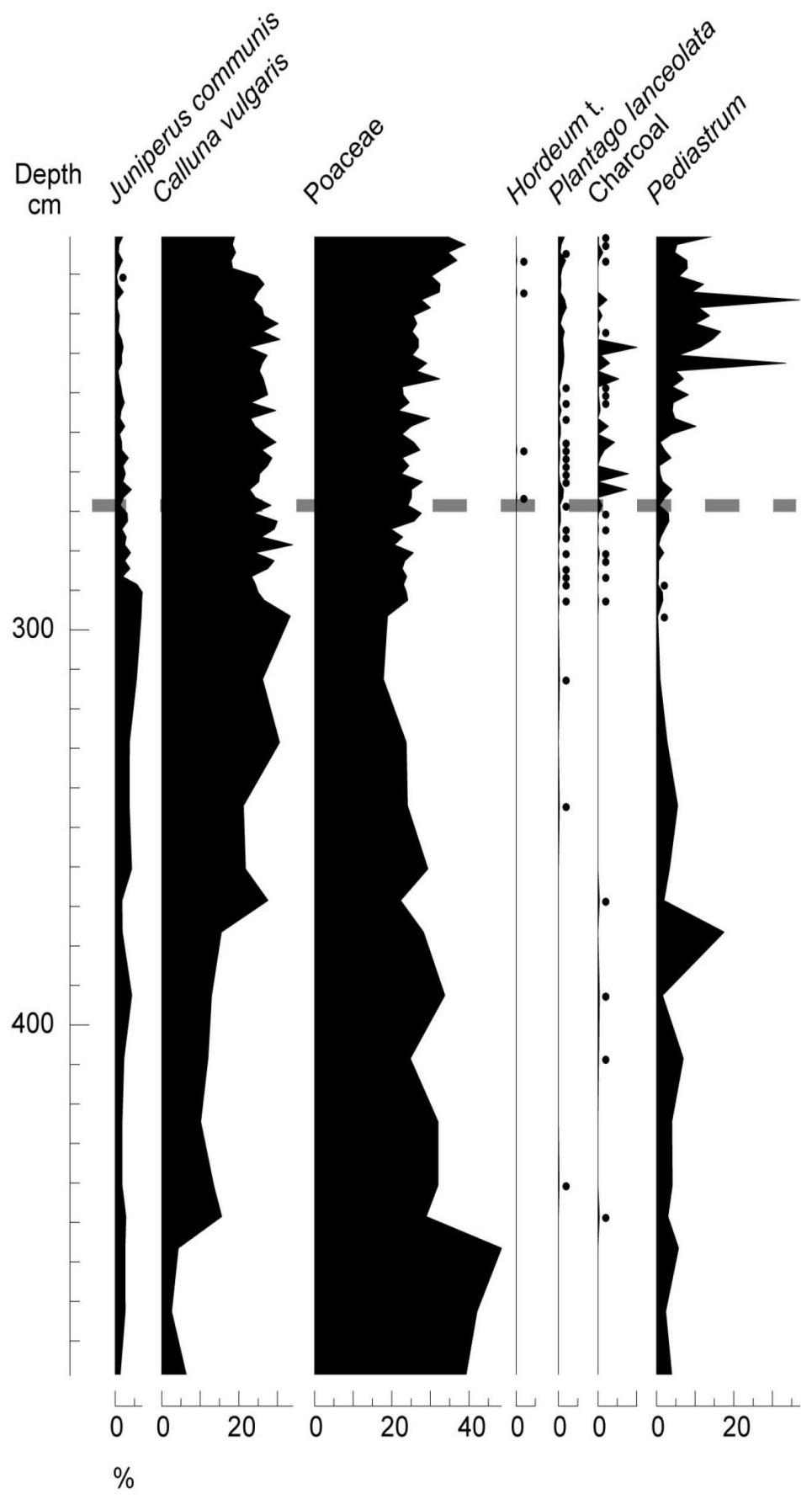

Figure 8. Summary pollen diagram for Gróthúsvatn. The dotted line indicates the approximate position of settlement (dating pending) based on presence of barley pollen and increased microcharcoal. 
Another feature of the Western Isles assemblages was the presence of other cereals (Table 5), such as oat (Avena strigosa type) and traces of rye (Secale cereale L.) and wheat (Triticum sp.) as well as flax (Linum usitatissimum L.). Only two grains of oat were found in the Junkarinsfløtti assemblage, and these may have been weeds of the barley crop. In the Faroes, only barley grains were recovered from the landnám period farm at Toftanes (Vickers et al. in press). Also, most of the cereal grains found in settlement period pollen diagrams have been of barley type (cf. Jóhansen 1985; Hannon et al. 2001). Though more archaeobotanical assemblages need to be analyzed, it seems that a barley monoculture was in place and that a deliberate decision was made not to grow other crops clearly known to the settlers. It is probable that flax and rye would perform very poorly in the soil and climatic conditions of the Faroes (Zohary and Hopf 1994). However, this would not be the case for oat, which could have been economically viable in the soils of the Faroes and was becoming an increasingly important crop throughout Atlantic Scotland during the Norse period (Boyd 1988; Dickson and Dickson 2000; Church 2002a; Bond 2002). This concentration on barley cultivation may have been due to the positive response of barley (in terms of increased yields) to deliberate amendment of the soil. In comparison, oat does not increase yield significantly with soil amendment (Bond 2002). Through detailed analysis of palaeosols, Adderley and Simpson (in press) demonstrated that soils of infield areas across the Faroes were routinely amended since the settlement period. Therefore, it is possible that the labor investment that could be afforded for cereal cultivation was exclusively channeled into barley cultivation in small fields of heavily fertilized soils.

The ubiquitous presence of chickweed (Stellaria media L. Vill.) in all three phases at Junkarinsfløtti indicated relatively nitrogenous soil conditions (Sobey 1981) in certain areas. Assuming that the chickweed was a weed of the barley crop (but note that the plant is also associated with other plant communities as well as cultivated land, Fosaa 2000; 2001), this may have indicated field rotation between pastoral and arable agriculture, on a seasonal or spatial basis, or the deliberate incorporation of dung into the soil as a fertilizer and stabilizer. However, the other wild species represented a mix of species from cultivated ground, wet pasture, and moorland (Grime et al. 1988; Stace 1994; Fosaa 2000; 2001). These plants, from mutually exclusive ecological niches, would have been mixed together in the domestic hearths burning peat/turf or dung as fuel and then dumped down slope onto the middens sampled. This mixing is a common feature of archaeobotanical assemblages in the North Atlantic (Church and Peters 2004) and greatly complicates detailed analysis of specific plant ecologies, such as the weeds associated with the barley crop.

The procurement of wood would have been a major consideration for the Norse in the Faroes. The islands never sustained extensive woodland (Jóhansen 1985; Hannon et al. 2001), and heather and juniper were the only wood resource available on Sandoy at settlement (Fig. 8 and see Lawson et al. in press). The few charcoal remains included ling heather and juniper (Juniperus sp.) roundwood that presumably represent native growth (Fosaa 2000), a few birch (Betula sp.) timber fragments that are doubtfully native (see Malmros 1990; 1994 for further discussion), and various coniferous timber species of larch (Larix sp.), pine (Pinus sp.), and spruce (Picea sp.) that would have arrived on the island as driftwood. This driftwood was presumably picked up from the shore and would have been a prized resource in the treeless landscape, needing social controls in place for its distribution 
through the local population. Driftwood use is well documented in this area of the North Atlantic during the Norse period in the Faroes at Argisbrekka (Malmros 1990; 1994) and Atlantic Scotland (Dickson 1992; Church 2002b), and its exploitation was regulated by legislation in early medieval Iceland (Dennis et al. 2000, 321-43). A few fragments of oak timber (Quercus sp.) were also recovered from the earliest phase that could not have grown locally and may represent imported material.

\section{Conclusions}

This paper has reported on the first zooarchaeological analysis undertaken for the Faroes and only the third archaeobotanical assemblage published from the islands. The preliminary analysis of these remains presents a diverse range of economic practices employed by the Norse settlers at a key time and geographical position in their expansion across the North Atlantic. Their economic strategy appears to have relied heavily upon the exploitation of a broad spectrum of local wild resources to supplement a mixed agricultural base of animal husbandry and cereal cultivation.

Domestic mammals recovered included sheep, cows, and pigs with single bones of goat and dog. Significant numbers of pig bones were recovered throughout the site sequence, indicating sustained pig keeping up to and beyond the 13th century, a situation unique compared to Iceland and Greenland. Birds composed a relatively large proportion of the archaeofauna. The Faroese at Junkarinsfløtti remained dependent upon bird resources, especially puffins, far longer and to a greater degree than any of the other Viking age settlers of the North Atlantic islands. A wide range of marine resources were also recovered, suggesting the Norse settlers of Faroes were heavily reliant on natural resources to sustain their economy.

Wood charcoal was very rare and consisted of locally derived roundwood, coniferous driftwood, and imported oak. Peat and turf were the main fuel sources in the treeless landscape. A hulled six-row barley monoculture was in place, with small-scale yet intensive cultivation undertaken. Cereal cultivation seems to have played a lesser role in the economy than other areas of the eastern North Atlantic, and some of the barley may have been imported.

Acknowledgments - The authors would like to thank the Leverhulme Trust "Landscapes circumlandnám" program, the US National Science Foundation Arctic Social Sciences Program, and the CUNY Northern Science and Education Center for funding support. We thank Ragnar Edvardsson, Matt Brown, and Juha Martilla for their hard and expert work in the field in 2003-2004. Thanks are also due to Julie Bond and Steve Dockrill for their good advice and council; to Jill Barber, Kate Smith, Julie Mitchell, and Maureen Lamb for technical and logistical support; and to the farmer Harald Jensen, the people of Sandur and Sandoy, and their mayor Páll á Reynatúgvu for kind permission for access to sites and substantial help with excavations. Professor Jim Dickson is thanked for access to unpublished material from Barvas. We would also like to thank the editor and reviewers for their helpful comments. 


\section{References}

Adderley, W. P., and Simpson, I. A. in press. Agro-ecosystem sustainability of early Norse cereal production in Faroes. Human Ecology 33.

Amorosi, T. 1992. Climate impact and human response at Svalbarð Farm, north east Iceland, pp. 131152 in Morris, C. D., and Rackham, J. (eds.), Norse and Later Settlement and Subsistence in the North Atlantic. Glasgow: Glasgow University Press.

Amorosi, T. 1996. Icelandic Zooarchaeology and Global Change Research: New Data Applied to Issues of Historical Ecology, Paleoeconomy and Global Change. Unpublished PhD thesis, City University of New York.

Amorosi, T., Woollett, J. M., Perdikaris, S., and McGovern, T. H. 1996. Regional zooarchaeology and global change: problems and potentials. World Archaeology 28, 126-57.

Amundsen, C. 2004. Farming and maritime resources at Midbaer on Flatey in Breiðfjörd, north west Iceland, pp. 203-10 in Housley, R., and Coles, G. M. (eds.), Atlantic Connections and Adaptations: Economies, Environments and Subsistence in Lands Bordering the North Atlantic. Oxford: Oxbow.

Amundsen, C., Perdikaris, S., McGovern, T. H., Krivogorskaya, Y., Brown, M., Smiarowski, K., Storm, S., Modugno, S., Frik, M., and Koczela, M. in press. Thirteenth and fifteenth century archaeofauna from the seasonal fishing site of Akurvík, north west Iceland. Environmental Archaeology 10.

Anderberg, A.-L. 1994. Atlas of Seeds: Part 4, Resedaceae-Umbelliferae. Stockholm: Swedish Museum of Natural History.

Arge, S. V. 1991. The landnám in the Faroes. Arctic Anthropology 28, 101-20.

Arge, S. V. 1993. On the landnám of the Faroe Islands, pp. 465-72 in Batey, C. E., Jesch, J., and Morris, C. D. (eds.), The Viking Age in Caithness, Orkney and the North Atlantic. Edinburgh: Edinburgh University Press.

Arge, S. V. 1997. Í Uppistovubeitinum. Site and settlement. Fróðskaparrit 45, 27-44.

Arge, S. V. 2001. Forn búsetning heima á Sandi (Recent archaeological investigations at Sandur). Frødi 2, 5-13.

Arge, S. V. in press. Uttangarðs: a characteristic of relics in the Faroe outfield, in Holm, I., Inselset, S. and Øye, I. (eds.), Utmark (The Outfield/Wasteland) as Industry and Ideology in the Iron Age and Middle Ages. Bergen: University of Bergen.

Arneborg, J., Heinemeier, J., Lynnerup, N., Nielsen, H. L., Rud, N., and Sveinbjörnsdóttir, Á. E. 1999. Change of diet of the Greenland Vikings determined from stable carbon isotope analysis and 14C dating of their bones. Radiocarbon 41, 157-68.

Ascough, P. L., Cook, G. T., Dugmore, A. J., Barber, J., Higney, E., and Scott, E. M. 2004. Holocene variations in the Scottish marine radiocarbon reservoir effect. Radiocarbon 46, 611-20.

Ascough, P. L., Cook, G. T., Church, M. J., Dugmore, A. J., Arge, S. V., and McGovern, T. H. in press. Variability in North Atlantic marine radiocarbon reservoir effects at c. 1000 AD. The Holocene.

Barrett, J. H., Beukens, R. P., and Nicholson, R. A. 2001. Diet and ethnicity during the Viking colonization of Northen Scotland: evidence from fish bones and stable carbon isotopes. Antiquity 75, $145-54$

Beijerinck, W. 1947. Zadenatlas der Nederlandsche Flora. Wageningen: Veenman.

Berggren, G. 1969. Atlas of Seeds, Part 2, Cyperaceae. Stockholm: Swedish Museum of Natural History.

Berggren, G. 1981. Atlas of Seeds, Part 3, Salicaceae-Cruciferae. Stockholm: Swedish Museum of Natural History. 
Benecke, N. 1993. On the utilization of domestic fowl in central Europe from the Iron age up to the Middle ages. Archaeofauna 2, 21-31.

Bennike, O., Böcher, J., Konradi, P., Kuijpers, A., and Larsen, B. 1998. Macrofossil studies of lacustrine sediments from Skálafjørður, the Faroe Islands: preliminary results. Fróðskaparrit 46, 267-75.

Biddick, K. 1984. Pig husbandry at the Peterborough abbey estate from the 12th to the 14th century AD, pp. 231-34 in Grigson, C., and Clutton-Brock, J. (eds.), Animals and Archaeology 4: Husbandry in Europe (BAR International Series 227). Oxford: British Archaeological Reports.

Bigelow, G. F. 1985. Sandwick Unst and the late Norse Shetlandic economy, pp. 95-127 in Smith, B. (ed.), Shetland Archaeology, New Work in Shetland in the 1970's. Lerwick: Shetland Times Press.

Bond, J. 2002. Pictish pigs and celtic cowboys: food and farming in the Atlantic Iron age, pp. 177-184 in Ballin-Smith, B., and Banks, I. (eds.), In the Shadow of the Brochs: the Iron Age in Scotland. Stroud: Tempus Publishing.

Boyd, W. E. 1988. Cereals in Scottish antiquity. Circaea 5, 101-10.

Bronk Ramsey, C. 2003. OxCal Version 3.9. (http://www.units.ox.ac.uk/departments/rlaha/orau/06_ind .html).

Buck, C. E., Cavanagh, W. G., and Litton, C. D. 1996. Bayesian Approach to Interpreting Archaeological Data. Chichester: Wiley.

Buckland, P. 1990. Insects, man and the earliest settlement of the Faroe Islands: a case not proven. Fróđskaparrit 39, 107-13.

Buckland, P. C., and Dinnin, M. H. 1998. Insect faunas at Landnám: a palaeoentomological study at Tjørnuvík, Streymoy, Faroe Islands. Fróđskaparrit 46, 277-86.

Buckland, P. C., Edwards, K. J., Sadler, J. P., and Dinnin, M. H. 1998. Late Holocene insect faunas from Mykines, Faroe Islands, with observations on associated pollen and early settlement. Fróðskaparrit 46, 287-296.

Cerón-Carrasco, R. 1998. Fishing: evidence for seasonality and processing of fish for preservation in the Northern Islands of Scotland during the Iron Age and Norse times. Environmental Archaeology 3, 73-81.

Charles, M. 1998. Fodder from dung: the recognition and interpretation of dung-derived plant material from archaeological sites. Environmental Archaeology 1, 111-21.

Church, M. J. 2002a. Plants and People in the Later Prehistoric and Norse Periods of the Western Isles of Scotland. Unpublished PhD thesis, University of Edinburgh.

Church, M. J. 2002b. Archaeobotanical considerations of a conflagration in Dun Bharabhat, Lewis, pp. 67-75 in Ballin-Smith, B. and Banks, I. (eds.), In the Shadow of the Brochs: the Iron Age in Scotland. Stroud: Tempus.

Church, M. J., and Peters, C. 2004. Application of mineral magnetism in Atlantic Scotland archaeology 2: archaeobotanical taphonomy in Atlantic Scotland, pp. 99-112 in Housley, R., and Coles, G. M. (eds.), Atlantic Connections and Adaptations: Economies, Environments and Subsistence in Lands Bordering the North Atlantic. Oxford: Oxbow.

Clapham, A. R., Tutin, T. G., and Moore, D. M. 1989. Flora of the British Isles (3rd ed.). Cambridge: Cambridge University Press.

Cowie, T. 1987. Barvas. Discovery and Excavation in Scotland, 1987, 62.

Dean W. E. 1974. Determination of carbonate and organic matter in calcareous sediments and sedimentary rocks by loss on ignition: comparison with other methods. Journal of Sedimentary Petrology 44, 242-48.

Dearing, J. 1994. Environmental Magnetic Susceptibility. Kenilworth: Chi Publishing. 
Debes, H. J. 1993. Problems concerning the earliest settlement in the Faroe Islands, pp. 454-64 in Batey, C. E., Jesch, J., and Morris, C. D. (eds.), The Viking Age in Caithness, Orkney and the North Atlantic. Edinburgh: Edinburgh University Press.

DeNiro, M. J. 1985. Postmortem preservation and alteration of in vivo bone collagen isotope ratios in relation to palaeodietary reconstruction. Nature 317, 806-9.

Dennis, A., Foote, P., and Perkins, R. 2000. The Laws of Early Iceland Grágás 2. Winnipeg: University of Manitoba Press.

Dickson, C. A. 1979. Carbonised plant macrofossils from Barvas machair, Lewwis. Unpublished technical report for the National Museum of Scotland.

Dickson, C. A. 1994. Plant remains, pp. 125-39 in Ballin Smith, B. (ed.), Howe: Four Millennia of Orkney Prehistory (Society of Antiquaries of Scotland Monograph Series 9). Edinburgh: Society of Antiquaries of Scotland.

Dickson, C. A. 1998. Past uses of turf in the Northern Isles, pp. 105-9 in Milles, C., and Coles, G. M. (eds.), On the Edge: Settlement in Marginal Areas. Oxford: Oxbow.

Dickson, C. A., and Dickson, J. H. 2000. Plants and People in Ancient Scotland. Stroud: Tempus.

Dickson, J. H. 1992. North American driftwood, especially Picea (spruce), from archaeological sites in the Hebrides and Northern Isles of Scotland. Review of Palaeobotany and Palynology 73, 49-56.

Dugmore, A. J., and Newton, A. J. 1998. Holocene tephra layers in the Faroe islands. Fródskaparrit 46, 191-204.

Dugmore, A. J., Church, M. J., Buckland, P. C., Edwards, K. J., Lawson, I., McGovern, T. H., Panagiotakopulu, E., Simpson, I. A., Skidmore, P., and Sveinbjarnardóttir, G. 2005. The Norse landnám on the north Atlantic islands: an environmental impact assessment. Polar Record 41, 21-37.

Edwards, K. J., Buckland, P. C., Craigie, R., Panagiotakopulu, E., and Stummann Hansen, S. 1998. Landscapes at landnám: palynological and palaeoentomological evidence from Toftanes, Faroe Islands. Fróðskaparrit 46, 229-44.

Edwards, K. J., Buckland, P. C., Dugmore, A. J., McGovern, T. H., Simpson, I. A., and Sveinbjarnardóttir, G. 2004. Landscapes circum-landnám: Viking settlement in the North Atlantic and its human and ecological consequences: a major new research programme, pp. 260-271 in Housley, R., and Coles, G. M. (eds.), Atlantic Connections and Adaptations: Economies, Environments and Subsistence in Lands Bordering the North Atlantic. Oxford: Oxbow.

Einarsson, B. F. 1994. The Settlement of Iceland: a Critical Approach: Granastadir and the Ecological Heritage (Gothenburg Archaeological Theses 4). Gothenburg: University of Gothenburg.

Enghoff, I. B. 2003. Hunting, Fishing, and Animal Husbandry at the Farm Beneath the Sand, Western Greenland: an Archaeozoological Analysis of a Norse Farm in the Western Settlement (Meddelelser om Grønland, Man and Society 28). Copenhagen: Meddelelser om Grønland.

Fosaa, A. M. 2000. Wildflowers in the Faroe Islands. Torshavn: Føroya Náttúrugripasavn.

Fosaa, A. M. 2001. A review of plant communities of the Faroe islands. Fróøskaparrit 48, 41-54.

Grime, J. P., Hodgson, J. G., and Hunt, R. 1988. Comparative Plant Ecology: a Functional Approach to Common British Species. London: Unwin Hyman.

Gupta, S. K., and Polach, H. A. 1985. Radiocarbon Dating Practices at ANU. Canberra: Australian National University.

Hannon, G. E., Hermanns-Auðardóttir, M., and Wastegård, S. 1998. Human impact at Tjørnuvík on the Faroe islands. Fróøskaparrit 46, 215-28.

Hannon, G. E., and Bradshaw, R. H. W. 2000. Impacts and timing of the first human settlement on vegetation of the Faroe islands. Quaternary Research 54, 404-13. 
Hannon, G. E., Wastegård, S., Bradshaw, E., and Bradshaw, R. H. W. 2001. Human impact and landscape degradation on the Faroe islands. Biology and Environment: Proceedings of the Royal Irish Academy 101B, 129-39.

Heiri, O., Lotter, A. F., and Lemcke, G. 2001. Loss on ignition as a method for estimating organic and carbonate content in sediments: reproducibility and compatibility of results. Journal of Palaeolimnology 25, 101-10.

Hodgson, J. M. (ed.) 1976. Soil Survey Field Handbook (Soil survey of England and Wales Technical Monograph 5). London: Soil survey of England and Wales.

Hubbard, R. N. L. B., and al Azm, A. 1990. Quantifying preservation and distortion in carbonised seeds, and investigating the history of friké production. Journal of Archaeological Science 16, 103-6.

Hutton-Macdonald, R., Macdonald, K. C., and Ryan, K. 1993. Domestic geese from Medieval Dublin. Archaeofauna 2, 205-18.

Jóhansen, J. 1971. A palaeobotanical study indicating a pre-Viking settlement in Tjørnuvík, Faroe islands. Fróðskaparrit 19,147-57.

Jóhansen, J. 1975. Pollen diagrams from the Shetland and Faroe islands. New Phytologist 75, 369-87.

Jóhansen, J. 1982. Vegetational development in the Faroes from 10,000 BP to the present. Danmarks Geologiske Undersegelse Årbog 1981, 111-36.

Jóhansen, J. 1985. Studies in the Vegetational History of the Faroe and Shetland Islands. Tórshavn: Føroya Fróðskaparfelag.

Jones, M. K. 1991. Sampling in palaeoethnobotany, pp. 53-62 in van Zeist, W., Wasylikowa, K., and Behre, K.-E. (eds.), Progress in Old World Palaeoethnobotany. Rotterdam: A. A. Balkema.

Kenward, H. K., Hall, A. R., and Jones, A. K. G. 1980. A tested set of techniques for the extraction of plant and animal macrofossils from waterlogged archaeological deposits. Science and Archaeology 22, 3-15.

Koch, P. L., Fogel, M. L., and Tuross, N. 1994. Tracing the diets of fossil animals using stable isotopes, pp. 63-92 in Lajtha, K., and Michener, R. H. (eds.), Stable Isotopes in Ecology and Environmental Science. Oxford: Blackwell Scientific Publications.

Lawson, I. T., Church, M. J., McGovern, T., Arge, S. V., Woollett, J. W., Edwards, K. J., GathorneHardy, F. J., Dugmore, A. J., Mairs, K.-A., Thomson, A. M., and Sveinbjarnardóttir, G. in press. Historical ecology on Sandoy, Faroe islands: palaeoenvironmental and archaeological perspectives. Human Ecology 33.

Long, H. C. 1929. Weeds of Arable Land. London: HMSO.

Mahler, D. D. 1993. Sheilings and their role in the Viking age economy: new evidence from the Faroe islands, pp. 487-505 in Batey, C. E., Jesch, J., and Morris, C. D. (eds.), The Viking Age in Caithness, Orkney and the North Atlantic. Edinburgh: Edinburgh University Press.

Malmros, C. 1990. Viking age wood resources at Argisbrekka, Faroe islands. Norwegian Archaeological Review 23, 86-92.

Malmros, C. 1994. Exploitation of local, drifted and imported wood by the Vikings on the Faroe islands. Botanical Journal of Scotland 46, 552-8.

McLaughlin, K. 1980. Traditional Fuels of the Outer Hebrides: the Modern Charred Seed Assemblages. Unpublished MSc dissertation, University of Sheffield.

McGovern, T. H. 1985. Contributions to the paleoeconomy of Norse Greenland. Acta Archaeologica $54,73-122$.

McGovern, T. H. 2004. North Atlantic Biocultural Organization (NABO) 10 years on: science, education, and community, pp. 254-59 in Housley, R., and Coles, G. M. (eds.), Atlantic Connections and 
Adaptations: Economies, Environments and Subsistence in Lands Bordering the North Atlantic. Oxford: Oxbow.

McGovern, T. H., Buckland, P. C., Sveinbjarnardóttir, G., Savory, D., Skidmore, P. and Andreasen, C. 1983. A study of the faunal and floral remains from two Norse farms in the Western Settlement, Greenland. Arctic Anthropology 20, 93-120.

McGovern, T. H., Bigelow, G. F., Amorosi, T., Woolett, J. W., and Perdikaris, S. 1993. Animal bones from E17a Narsaq, pp. 101-22 in Vebaek, C. L. (ed.), Narsaq: a Norse Landnám Farm (Meddelelser om Grønland, Man and Society 18). Copenhagen: Meddelelser om Grønland.

McGovern, T. H., Amorosi, T., Perdikaris, S., and Woollett, J. W. 1996. Zooarchaeology of Sandnes V51: economic change at a chieftain's farm in west Greenland. Arctic Anthropology 33, 94-122.

McGovern T. H., Perdikaris, S., and Tinsley, C. 2001. Economy of landnám: the evidence of zooarchaeology, pp. 154-166 in Wawn, A., and Sigurðardottir, T. (eds.), Approaches to Vinland (Nordahl Institute Studies 4). Reykjavik: Nordahl Institute Studies.

McGovern, T. H., Amundsen, C., Perdikaris, S., Harrison, R., and Krivogorskaya, K. 2004. An interim report of a Viking Age and Medieval archaeofauna from Undir Junkarinsfløtti, Sandoy, Faroe Islands. Unpublished NORSEC Zooarchaeological Laboratories Report 17.

Miller, N. F., and Smart, T. L. 1984. Intentional burning of dung as fuel: a mechanism for the incorporation of charred seeds into the archaeological record. Journal of Ethnobiology 4, 15-28.

Neighbour, T., and Burgess, C. P. 1997. Bostadh (Uig Parish). Discovery and Excavation in Scotland 1996, 113-14.

Neighbour, T., and Church, M. J. 2001. The eroding settlement and Iron Age cemetery at Galson, Isle of Lewis. Unpublished Centre for Field Archaeology Report 635.

Outram, A. K. 1999. A comparison of palaeoeskimo and Medieval Norse bone fat exploitation in western Greenland. Arctic Anthropology 36, 103-17.

Outram, A. K. 2003. Comparing levels of subsistence stress amongst Norse settlers in Iceland and Greenland using levels of bone fat exploitation as an indicator. Environmental Archaeology 8, 119-28.

Pearsall, D. 2000. Palaeoethnobotany (2nd ed.). New York: Thames and Hudson.

Perdikaris, S. 1999. From chiefly provisioning to commercial fishery: long term economic change in Arctic Norway. World Archaeology 30, 388-402.

Perdikaris, S., Amundsen, C., and McGovern, T. H. 2002. Report of animal bones from Tjarnargata 3C, Reykjavík, Iceland. Unpublished report for the Fornleifastofnan Íslands, Reykjavik.

Peters, C., Church, M. J., and Mitchell, C. 2001. Investigation of domestic fuel sources on Lewis using mineral magnetism. Archaeological Prospection 8, 227-37.

Peters, C., Church, M. J., and Batt, C. 2004. Application of mineral magnetism in Atlantic Scotland archaeology 1: techniques, magnetic enhancement and the identification of fuel sources, pp. 8698 in Housley, R., and Coles, G. M. (eds.), Atlantic Connections and Adaptations: Economies, Environments and Subsistence in Lands Bordering the North Atlantic. Oxford: Oxbow.

Rasmussen, J. 1982. The Faeroe islands: geology, pp. 13-34 in Rutherford, G. K. (ed.), The Physical Environment of the Faeroe Islands. The Hague: Junk Publishers.

Renfrew, J. 1973. Palaeoethnobotany. London: Methuen.

Schweingruber, F. H. 1990. Microscopic Wood Anatomy. Geneva: Swiss Federal Institute for Forest, Snow and Landscape Research.

Simpson, I. A., Vésteinsson, O., Adderley, W. P., and McGovern, T. H. 2003. Fuel resource utilisation in landscapes of settlement. Journal of Archaeological Science 30, 1401-20. 
Sobey, D. G. 1981. Biological flora of the British Isles. Stellaria media (L.) Vill. Journal of Ecology 69, 311-35.

Stace, C. 1994. New Flora of the British Isles (2nd ed.). Cambridge: Cambridge University Press.

Stummann Hansen, S. 1993. Viking age Faroe islands and their southern links in the light of recent finds at Toftanes, Leirvík, pp. 473-86 in Batey, C. E., Jesch, J., and Morris, C. D. (eds.), The Viking Age in Caithness, Orkney and the North Atlantic. Edinburgh: Edinburgh University Press.

Sveinbjörnsdóttir, A. E., Heinemeier, J., and Gudmundsson, G. 2004. 14C dating of the settlement of Iceland. Radiocarbon 46, 387-94.

van der Veen, M. 1992. Crop Husbandry Regimes: an Archaeobotanical Study of Farming in Northern England, 1000 BC-AD 500 (Sheffield Archaeological Monograph 3). Sheffield: Collis Publications.

Vickers, K., Bending, J., Buckland, P. C., Edwards, K. J., and Stummann Hansen, S. in press. Toftanes: the palaeoecology of a Faroese landnám farm. Human Ecology 33.

Ward, J., and Mainland, I. 1999. Microwear in modern rooting and stall fed pigs. Environmental Archaeology 4, 25-33.

Wastergård, S. 2002. Early to middle Holocene silicic tephra horizons from the Katla volcanic system, Iceland: new results from the Faroe Islands. Journal of Quaternary Science 17, 723-30.

Wheeler, A., and Jones, A. 1989. Fishes. Cambridge: Cambridge University Press.

Zohary, D., and Hopf, M. 1994. Domestication of Plants in the Old World. Oxford: Clarendon Press. 